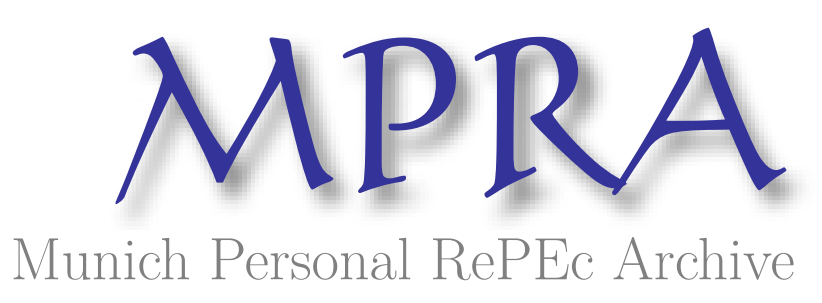

\title{
Accounting: A General Commentary on an Empirical Science
}

Salvary, Stanley C. W.

28 June 2007

Online at https://mpra.ub.uni-muenchen.de/5005/

MPRA Paper No. 5005, posted 23 Sep 2007 UTC 


\title{
ACCOUNTING: A GENERAL COMMENTARY ON AN EMPIRICAL SCIENCE
}

\author{
Stanley C. W. Salvary
}

We must rid ourselves of the belief that accounting cannot be an empirical science [Sterling 1979:213].

\begin{abstract}
Many researchers have questioned the view of accounting as a science. Some maintain that it is a service activity rather than a science, yet others entertain the view that it is an art or merely a technology. While it is true that accounting provides a service and is a technology (a methodology for recording and reporting), that fact does not prevent accounting from being a science. Based upon the structure and knowledge base of the discipline, this paper presents the case for accounting as an empirical science.
\end{abstract}

\section{1 - CLASSIFICATION OF ACCOUNTING}

Given its very long history, accounting is no stranger to the various problems associated with the development of a science [Salvary 1979;1985:8,12]. Accounting as a specific field of science was advanced by Werner Sombart (1916), who drew the distinction between accounting and administration. He reasoned that everything pertaining to accounting falls within the same domain; whereas those things that belong to administration are dispersed among a huge assembly of domains (e.g., psychology, sociology, political science, etc.). Sombart reserved to accounting the rules which constitute the code for the acquisition and dissemination of information to the organizational community [Most 1977:262].

Science is considered to be concerned with describing/explaining and predicting the empirical world - the identification of empirical laws. Essentially, the generalizations that permit description/explanation and prediction in science are empirical (deterministic and statistical) laws. While empirical deterministic laws are if-then always propositions, empirical statistical laws are based upon past experience and are highly probable statements. Empirical statistical laws are based on evidence which is cumulative, qualitatively similar, and purely statistical. They are supported primarily by induction. Empirical deterministic laws are based on evidence which is non-statistical, non-cumulative, and qualitatively dissimilar. They are supported more by deduction than any other considerations [Harre' 1970:11; Hanson 1969:335; Hempel 1965:175,301-302; Reichenbach 1963:6,157]. 
Unequivocally, to be accepted as a science, accounting must satisfy the necessary conditions as outlined above to demonstrate that it is indeed a science. While a natural science is identified as a closed system of cause and effect, accounting as an empirical science relates to an open system of stimulus and response [Salvary 1979:359-360]. In one study [Salvary 1989:29-36] productivity and capitalization are identified as empirical deterministic laws and continuity and bankruptcy are identified as empirical statistical laws in accounting. Since both explanation and prediction are present in accounting, formal recognition of the identified laws make a compelling case for accounting as a science in the community of sciences.

In a fashion similar to that of surveying, accounting originated as a practical art. While the former gave rise to geometry, the latter evolved from an art into an empirical science [Salvary 1989:1]. The origin of accounting and its axiomatic setting (as outlined in the following section) provide ample evidence that accounting is an administrative information science [Salvary 1985;1979]. In accordance with identified statistical laws (continuity and bankruptcy), a series of events, having quantitative characteristics, are captured by certain equations which are derived from inductions based upon empirical observations [Salvary 1989:33-47]. Those basic accounting equations reflect an axiomatic system and, hence, constitute a mathematical setting for deduction. The accounting equations permit the formulation of a precise system of differential equations.

As an information science, accounting generates information on past events (i.e., what has happened) and generates projections of possible future outcomes (i.e., evaluations of available alternatives for decision-making purposes). The accounting measurement system consists of three independent units: (1) the want satisfaction item - the physical good/service unit; (2) the measuring device and transfer (exchange) mechanism - the money unit; and (3) the interval during which events occur - the time unit - fiscal year or subdivision thereof. Within this setting, financial accounting describes what has been observed while managerial accounting predicts what will be observed under certain well defined conditions (if the underlying assumptions hold, then the outcome will be as predicted) [Salvary 1985:39-50].

Financial accounting information is input into managerial accounting, wherein data are analyzed and alternative courses of action are developed. The descriptions provided by financial accounting function as behavioral rules which are adhered to by the entity. These 
behavioral rules are subject to mathematical deduction. Managerial accounting draws upon past observations to make prediction about possible future states of the entity. With such information, management selects the course of action which satisfies its needs. Evidently, management exercises control over its plans, the end results of which are captured in financial accounting. In this setting, financial statements constitute the starting point in management's application of the scientific method. Financial accounting is an empirical method of testing the predictions of managerial accounting. Hence, the use of the output of financial accounting activates financial analysis which is the focus of managerial accounting [Salvary 1985:39-54]. Figure 1 below [Salvary 1989:31] captures the relationship between financial and managerial accounting.

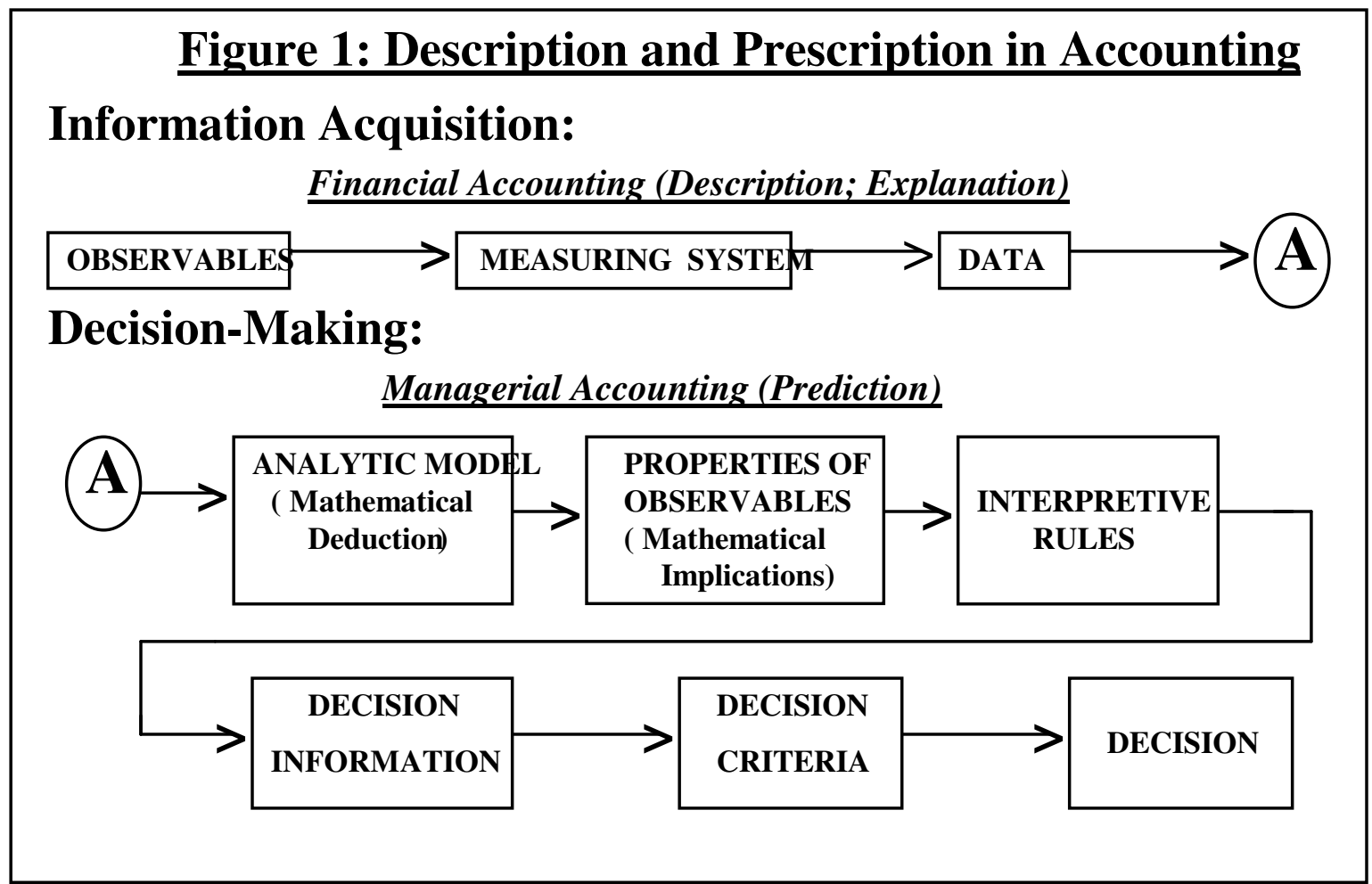

\section{[Adapted from Yovits and Ernst 1970:10]}

The roles of financial and managerial accounting as described above can readily be appreciated as depicted in antiquity in the following passage:

An elaborate system of account-keeping was required for the recording and for the planning based on it. Income and expenditures were scrupulously drawn up with summary balance statements by the officials of the separate districts. They were forwarded to the king's official in Ur, and so each year the agricultural yield could be planned. [Roebuck 1966:35] (Emphasis added.) 
Throughout the ages, a variety of measurement systems have been developed to accommodate the varying needs of society. Accounting, as it has evolved so far, is a library of quantifications in its social mission of describing and projecting occurrences in the socioeconomic system [Salvary 1985]. With the passage of time, the search will continue for answers to questions as they emerge.

The history of society reveals that there exists an evolutionary process of adaptation which is oriented toward the maximization of the social welfare. The social process is continually evolving as a consequence of the learning efforts and adaptive mode of society. Furthermore, various institutions and adaptive mechanisms have been introduced by society at various points in time in its attempt to enable a more efficient and effective execution of social exchanges. ..... The firm, money, a money economy, and the capital market have evolved over time providing clear examples of the social welfare maximizing adaptive process. In this evolutionary setting, the "procedure" and "property" of financial accounting measurement can be identified. [Salvary 1997,90]

In a world which is evolving, change can be expected when change is induced by changing conditions. Given an evolutionary setting, the continuing structural development of accounting would be within an axiomatic-empiric-pragmatic framework [Salvary 1989:26-27].

\section{2 - THE ORIGIN AND SPECIFIC FEATURES OF ACCOUNTING}

Based upon archaeological evidence, token accounting emerged around 8,000 B.C. Upon its emergence, three major functions - data storage, communication, and an instrument of logic characterized the token system of accounting [Schmandt-Besserat 1986:36-37]. Accounting emerged from a socio-political system [McNeill 1963:32-58] which extended into a trading system (a barter system initially and subsequently into a system in which money is exchanged for the goods and services produced). In order for society to manage its affairs, control over its resources had to be established. That need was the impetus for the invention of accounting as a first step in the administration of the affairs of society [Lambert 1960:1-26; McNeill 1963]. Control permitted: (1) a determination of the available resources within the jurisdiction of the administrators and (2) the management of the social needs to be satisfied with those resources. With control being established, accounting enables: (i) an evaluation of how resources were used during a specific period and (ii) an explanation of the disposition of such resources. 
The following passages provide a brief sketch of the progress of accounting along its early evolutionary development:

In Mesopotamia. . . . . by 3,000 B.C. or thereabouts, when decipherable documents permit more accurate knowledge of this ancient society, something already old, established, and in a real sense mature emerges for inspection; the civilization of the Sumerians . . . . .

Sumerian Civilization was a city civilization [in which] ... priests regularly served as managers, planners and co-ordinators of the massed human effort . . . . The priests alone possessed the skills of . . keeping accounts, without which effective co-ordination of community would have been impossible. . . . . . Writing began in Sumer as a symbolic accountancy, used to keep records of goods brought into or dispatched from temple storehouses. ... [W]riting was used for temple accounts, secondarily to record economic contracts between individuals, and scarcely at all for other purposes [McNeill 1963:32-58].

A large number of business records have come down to us from the period beginning about 2,600 B.C., dealing with sales, letting, hiring, money-lending, partnership, etc. The medium employed by the scribe in preparing these records was clay. . [Boyd 1905:16-17].

The public economy of the Athenians shows a highly developed system of accounting. .. [Boyd 1905:23]. (Emphasis added.) ${ }^{\mathbf{1}}$

Clearly from its origin, accounting is not identifiable with any specific concept of a profit motive. It is dispassionately free from any attachment and serves all sectors within a socioeconomic system. Currently, in most economies, there are three basic sectors:

1) Public - collectivistic (the common good);

2) Private - individualistic (profit oriented); and

3) Philanthropic - pluralistic (the specific welfare need).

The measurement unit is circumstantial or situational. The measurement unit is free of any specific alignment - resources can be accounted for in equivalent labor hours, bushels of wheat, ounces of gold, money, etc. In the social evolutionary setting as it evolved, the accounting measurement process is a function of: (1) the purpose for which the accounting report is designed and (2) the underlying accounting theoretical framework accepted by the society in question. Accounting measurement is derived from administrative life. It is quite evident that this condition manifested itself in Sumerian civilization [Salvary 1985:8]:

[At] Lagash, .... Scribes record without effort and difficulty the incoming and outgoing (goods) of the Palace. ... 
It suffices that at that period [of expanded human activity] a high ranking personage, scribe by profession, had established by taste rather than by necessity, a system of written control ....

In order to mitigate a growing disorganization, those in charge . . . [b]rought into their service some technical improvements in the sense of a greater control in the distribution of commodities . . . . which had become rare. [Lambert 1960:19-25.]

In ancient Egypt, . . . , the use of money was unknown, and the fiscal receipts and payments of Pharaoh were in kind ... The royal treasury partook of the character of the farm, the warehouse and the manufactory. [Boyd 1905:20]

As implied in the above passages, the measurement unit of accounting depended on the measurement that was conducive to sound control and administrative decision-making in allocating resources initially in national or macro accounting. Thus given the evolutionary progress of society, organizational or micro accounting emerged, in which labor units would be the unit of measurement when there was adherence to the labor standard of value; and ounces of gold/silver when there was adherence to a gold/silver standard of value.

[G]old and silver .... [were) regarded, in a world of steady farmers, as a convenient measure of value. For oxen ... were not always of the same value, whereas a bar of gold was always a bar of gold, .....

They were not used as a medium of exchange until 700 B.C. when coined currency (gold and silver) emerged. For it was then that "men began seriously to feel the need of a recognized common measure in their bargaining," to replace the time consuming effort of calculating the exact value of everything else. Coin currency (precious metals) established at a recognized value was issued for use in daily transactions; thus, a monopoly in exchange was created with money being the monopolistic agent [Zimmern 1961:302-303].

Given such progress in society, fiat money, as the medium of exchange, emerged as a measurement unit. Money, a fluid agent, accommodates the allocation of resources within and among organizations. With further development, a new accountability emerged to recognize: (1) risk-sharing arrangements entered into among suppliers of money; (2) the surrogate-market nature of the firm; and (3) the element which constitutes capital: money and credit. Measurement in the use of money permits an assessment of the efficiency/inefficiency in the management of time and other resources. Profit (the difference between money output and money input) as a measure of efficiency accommodates the new accountability [Salvary 1993:169,170]. This new accountability (micro-organizational level accounting) did not supersede nor duplicate the old accountability (macro-national level accounting). (See Section 12) 


\section{3 - DIFFERENCES BETWEEN ACCOUNTING AND ECONOMICS}

On one hand, as indicated in Table 1, financial accounting generates information that is descriptive. It measures and reports on actual behavior. Financial accounting describes what has been observed and how it has been accomplished; accordingly, it creates a data base. Being embedded in a positive theory, financial accounting reports on the effects of decisions but passes no judgment on the decisions. Managerial accounting provides data and analyses for decisionmaking and provides means for the evaluation of actual performance of implemented decisions. Being prescriptive, it outlines the course(s) of action that should be taken.

\begin{tabular}{|c|c|}
\hline \multicolumn{2}{|c|}{$\begin{array}{c}\text { TABLE } 1 \\
\text { ACCOUNTING: AN ADMINISTRATIVE INFORMATION SCIENCE }\end{array}$} \\
\hline \multicolumn{2}{|c|}{ Information Acquisition and Dissemination } \\
\hline$\frac{\text { OPEN SYSTEM: MANAGERIAL ACCOUNTING }}{\text { Planning/Feedforward }}$ & $\frac{\text { CLOSED SYSTEM: FINANCIAL ACCOUNTING }}{\text { Control/Feedback }}$ \\
\hline $\begin{array}{c}\text { Evaluation Orientation - Constructing and } \\
\text { Testing (using feedback) }\end{array}$ & $\begin{array}{l}\text { Observation Orientation - Operating and } \\
\text { Learning (using feedforward) }\end{array}$ \\
\hline $\begin{array}{l}\text { (1) Incremental Cost } \\
\text { Entry Value - Replacement Value }\end{array}$ & $\begin{array}{c}\text { Matching (A defined operation for measuring } \\
\text { organizational performance) } \\
\text { Identification of Benefits and Sacrifices }\end{array}$ \\
\hline $\begin{array}{l}\text { (2) Opportunity Cost } \\
\text { Exit Value - Realizable Value }\end{array}$ & $\begin{array}{r}\text { Realization (A quality control measurement } \\
\text { condition to insure the quality } \\
\text { of organizational performance) }\end{array}$ \\
\hline (3) Abandonment Cost & Critical Event for Determining \\
\hline $\begin{array}{l}\text { Use Value - Planned Value/ } \\
\text { Use Expectation }\end{array}$ & Admissible Benefits and Sacrifices \\
\hline $\begin{array}{l}\text { Decision Orientation - Financing and Investing } \\
\text { Liquidity Cost and Collateral Value }\end{array}$ & $\begin{array}{l}\text { Performance Orientation - Operating } \\
\text { Money Committed/Recoverable Cost (3) } \\
\text { Derived Benefit - Return on Investment } \\
\text { Redistribution of Income }\end{array}$ \\
\hline DECISION: EX ANTE CONCEPT & PERFORMANCE: EX POST CONCEPT \\
\hline $\begin{array}{l}\text { Risk Determination and Acceptance } \\
\text { Discounted Cash Flow of } \\
\text { Expected Revenue Stream } \\
=\text { Present Value of Investment }\end{array}$ & $\begin{array}{l}\text { Risk Accepted and Benefit Established } \\
\text { Actual Cash Outlay in } \\
\quad \text { Implementing the Decision } \\
=\text { Money Committed } \\
\quad \text { (Asset Portfolio/Cost Burden) }\end{array}$ \\
\hline$=$ Ex Ante Sunk Cost & $=$ Ex Post Sunk Cost \\
\hline
\end{tabular}

[Salvary 1985:51] 
Accounting is comprised of general principles pertaining to the environment from which it draws and serves. It is an administrative information science [Salvary 1979;1985;1989;1992]. "A science often is described as a systematic body of knowledge; a complete array of essential principles or facts, arranged in a rational dependence or connection; a complex of ideas, principles, laws forming a coherent whole. . ." [Johnson; Kast; and Rosenzweig 1967:4]. Consistent with the foregoing description, accounting emerges as an empirical science. Specifically, it is concerned with events and measures relevant to efficient organizational control and planning.

In a technical sense, while giving due cognizance to the disciplines of economics, sociology, and psychology, accounting accumulates data, measures, processes, and generates information. Events are identified, measured, and documented. After the relevant data are processed, information concerning such events are generated and communicated in an unbiased manner. In a behavioral sense, managerial accounting information (in the form of projections, budgets, variance analysis, etc.) evokes emotional responses from performers (managers and employees) within organizations. Communication (the reporting) of such information facilitates the administration of simple and complex organizational activities. The means of communications are in the form of accounting reports. Being consistent with communication theory, the accounting process is characterized by three features:

(1) Transmission - Inputs, Processes, Outputs.

(2) Medium/Channel - Financial Statements, Managerial and Special Reports

(3) Reception/Decoding - Analysis by Users

Within the transmission aspect, inputs are the events as they are filtered and measured; they provide a basis for analyses and evaluations of performance, and projections. The processes constitute the recording methodology for documentation. The outputs would be the information as determined by the reporting methodology. All three areas are critical to a theory of accounting, however, some authors seem to believe that only the output area is accounting. ${ }^{2}$

Accounting is concerned with: (1) identifying and measuring resources to enable control over such resources and (2) establishing ownership interests and rights of identified parties. It involves the collecting, processing, and storing of specific information on resources in a manner that permits an awareness of the existence of such resources, their location, the manner in which 
they have been used, and the consequences resulting from such uses. Accounting information enables owners of resources and pertinent parties to make informed decisions.

Economics, being primarily prescriptive, is embedded in a normative theory [Mattesich 1964:235; Shwayder 1971]. Judging from Xenophon's Ways and Mean, Steuart's Economy [1767], and Adam Smith's Wealth of Nations [1776], economics focuses on the optimum allocation of resources and prescribes optimal decision-making rules. It involves analysis aimed at prescription. Since it prescribes behavior, economics is an optimization science [Meltzer 1983:66-78; Frazer and Boland 1983:129-144; Ackley 1983:1-16]. Being that economic analysis attempts to provide guidance as to what should be done and how it should be done, it proceeds from a data base that is generated by financial accounting.

The significant embryo of economics is found around 700 B.C. [Gordon 1975:1-3]. The reason for this late start in economics is simply because that discipline focuses mainly on: (1) choice - the decisions of units (organizations) and (2) some form of competition - the impact on resources due to increasing interaction of units (organizations) [Hiemann 1945:6-12; Haney 1949:28-34]. Owing to the nature of its mission, there is a certain dependence of economics on accounting (as a data base). According to Hudson [1970], Hicks [1968:141], Burstein [1963:105-107,122-125,137-138], and Boulding [1950:26-35,246-251,274]: Any accounting format is implicitly the conceptual framework for an economic model. In retrospect from a modern perspective, such a dependence can be inferred from the following passage.

It is true that their operations were not wholly 'capitalist,' for, without any adequate system of accounting and with weakly developed means of written communication over long distances, their profits were accumulated somewhat haphazardly, business decisions being made more on the basis of intuitive judgement than of economic rational planning [Brooklyn College 1960:71]. (Emphasis added.) ${ }^{\mathbf{3}}$

Another significant difference between the two disciplines is the primary objective in society ushering forth their emergence. In the case of accounting, control over resources is the first important function as suggested by the following statement:

Nothing was given out of the treasury without a written order. Peculation on the part of the workmen was provided against by the records of one offical checking those of another. When the corn was brought to the storehouses, each sack was filled in the sight of the overseer and noted down, and then the sacks were carried to the roof of the storehouse and emptied through the receiving opening, the scribe stationed there recorded the number received [Boyd 1905:21]. 
The origin of economics and importance of its undertaking is found in the following:

The earliest reference points for charting the emergence of economic thought are found about 700 B.C. At that time, an entirely oral tradition of discourse and education began to give way in Greek culture to written communication. ....

As early as the sixth century B.C., there is evidence of a trend towards a scientific approach to the understanding of social issues. An important influence was the work of Pythagoras of Samos. Born about 580 B.C. he had established by the end of the century a brotherhood of thinkers. . . . Social and political problems of the day were also of concern to them, and in these matters they emphasized the new technique of reasoning by means of numbers. This development of the possibilities of pure mathematics was a major stimulus to the achievement of a new degree of abstraction and conceptualization in social thought. Another contribution to the same movement was begun in Miletus, an Ionian coastal town, to the east of Athens. . . Thales was the pioneer here, and he was followed by Anazimander and Anaximenes ...

For the earliest stirrings of economic analysis it is necessary to look back to the period before the economic ascendancy of Athens and the surrounding region of Attica. The stirrings are evident in the poetry of Hesiod, composed about the middle of the eighth century B.C. His picture of an economy is in marked contrast to the one with which Athenians were to become familiar. Notably, the poet has only a faint grasp of the mechanisms of economic growth. Yet in his Work and Days, he gives an exposition of 'the economic problem' as it appears to be understood by many writers of economic textbooks today. In fact, there are strong affinities between Hesiod's account of the matter and that provided by Lord Robbins in his influential, "An Essay on the Nature and Significance of Economic Science (1932)" [Gordon 1975:1-3].

As stated earlier, economics is concerned with optimizing behavior given certain constraints. In this regard it is interesting to note the implication from Hesiod's environment:

His world is that of the small-scale subsistence farm, isolated from market involvements, and striving to maintain self-sufficiency. . .

Hesiod is intent on the solution of a particular problem: how can one explain the existence of an obligation to work? . .

The Works and Days is designed for recitation with musical accompaniment. Its 828 verses are broken up into small groups. .. Of these groups, those comprising the first 383 verses are of greatest interest, since they contain a well-conceived treatment of the problems of scarcity, choice, and allocation of resources at a microeconomic level. . .

Hesiod begins by outlining the economic problem, stressing its universal urgency and explaining its origins. . . Hesiod introduces the notion of scarcity of resources. .. [Gordon 1975:3-4]. (Emphasis added.) 
As noted above, accounting and economics are concerned with human behavior. Accounting is concerned with the control and planning of activities entailing social exchanges; and economics is concerned with rational allocation of resources and the policy implications of such behavior. It is important to note that economics loses its relevance in the case of abundance or extreme dearth - in these instances, rational allocation activity is not relevant [Gordon 1975:5]; yet accounting is not constrained by 'poverty or plenty'.

In summary, as opposed to deriving functional relationship in order to devise means for need satisfaction purposes [Johnson and Kroos 1953:2-3], accounting as a systemic information science is differentiated from the general class of need-satisfaction sciences, in that accounting generates information about the system. It is economics that discovers and analyzes "the hidden laws of coordination and integration in a free economy [Hiemann 1945:9]." In contrast, accounting is concerned with identifying certain aspects of the economic process [Lisle 1900:1; Paton and Stevenson 1916:13]. According to Gurley and Shaw [1960:26]: accounting describes "how spending units behave on the economy's market."

\section{4 - THE ORIGINS OF MONEY AND THE MONETIZATION OF THE ECONOMY}

Evolving out of social exchange as a social welfare maximizing device, money was assigned its roles in the transition from payment in kind to payment in nominal money terms. As transactions were executed in this manner, money emerged as the measure of want

satisfaction in the economic system. ${ }^{4}$ However, it is important to note that the mere existence of money is no indication that a monetary economy exists. It was during the period 1200-1500 AD that a monetary economy emerged. In that period, the manorial system evolved from a natural economy into a money economy [Lipson 1959:62,89,94,96,102; Finley 1973:140-141; Powell 1916:3-4]. Although the ancient world created hard money (gold and silver coins), it "never created fiduciary money in any form, or negotiable instruments." Quite simply, the mechanism for the creation of credit through negotiable instruments did not exist [Finley 1973:141]. ${ }^{\mathbf{5}}$ In Italy, bills of exchange emerged in the fourteenth century [Jevons 1875:294].

Initially, money was introduced as a unit of account (an imaginary unit) to facilitate exchange; the physical exchange ratios of all commodities were translated into a series of relative money prices. Accounting for physical quantities, while still being important, became 
subordinate to accounting for nominal money measures. Next, through the use of documents which evidenced that exchanges had taken place, money as a medium of exchange was introduced--a credit instrument representing an obligation emerged and this was transferable in settlement of an exchange. Subsequently, money became a store of uncertain value with the rise of the money and capital markets--the advent of third party financing of production. Then, a system of monetary exchange emerged retaining the historical mechanism of exchange--the varying set of exchange ratios of commodities in the form of nominal money prices.

\subsection{Monetization of the Economy}

From its inception, the institutional arrangement of money in society permitted the expression of the relationship of all commodities-one to another and each to every other-at a given point in time. ${ }^{6}$ As an arbitrary measure, money served as a measure of the value of goods and services exchanged at a given point in time, and whenever the value of those goods and services did change, the money measure clearly reflected such change. In this fashion, by making clear the resultant inequities of changing conditions on the working populace, money removed some of the inequities that were existent in a barter economy. [Babbage 1835:309-311; Malynes 1622; Cunningham and McArthur 1896:165]. Money gave rise to the concept of price level, which was absent in a barter economy.

In its earliest stage, money as a measure of value did not possess any physical quality. It was an imaginary concept, ${ }^{7}$ which functioned as a value measure primarily for calculating. With the passage of time, a money form (a medium of exchange) was introduced which, being generally acceptable, enhanced exchange and permitted a uniform command over goods and services (purchasing power) [Steuart 1767:408-413]. From this stage and onwards, it provided

a means of trading labor services for commodities without holding commodities. Thus, by enhancing specialization, money increased the efficiency of the economic system [Hendrickson 1970:29-30].

According to Leijonhufvud [1981:68-70]: money wages are required by individuals because firms do not produce a balanced basket of goods. Since they do not commit themselves in advance to a specific future consumption pattern, consumers want wealth in a form which permit the potential of consuming in the future whatsoever is then desirable. 


\subsection{Money: An Allocative/Organizing Agent}

The general acceptance of money by the members of society has been characterized by Weber [1947:112] as a form of "social action". Invariably, to members of society, goods and services do not possess the quality of general acceptability. Possessing general acceptability as a unique characteristic, money is an effective agent for organizing economic activities [White 1984:703, 708; Smith 1985:1184; Hendrickson 1970:26-27]. Also, being a fixed claim [Spindt 1985:177], money is a buffer stock against transactions requirement and enables an extension of the production period.

Conceptually, money is substitutable for goods and services which are indivisible. By attaching financial divisibility to goods and services, a money economy has resulted in the standardization and the systematization of the labor and commodity markets [Mitchell 1927:116;1967:603; Hendrickson 1970:21-22]. Unequivocally, a monetary economic system has extended the possibilities of the economic system far beyond the normal possibilities of a barter economic system [Burstein 1963:504-506; Babbage 1835:309-311; Eiriksson 1954:196; Lauderdale 1804:185-195,201].

\subsection{Types of Money: Commodity Money and Paper/Nominal Money}

Money, depending on its composite substance, can possess dual value - an extrinsic value as a medium of exchange and an intrinsic value, i.e, an independent value inherent in its composite substance [Walsh 1903:31; Newlyn 1962:3]. Precious metals - gold and silver coins ${ }^{8}$ are in this category. In earlier times, although being ornate objects they were circulated as currency. Facilitating exchange was the primary use of a commodity as money--the medium of exchange.

In recent times most economies are based upon paper (fiduciary/fiat) money which, while possessing an assured nominal value, is a store of an uncertain future value (i.e., a nonspecified purchasing power) [Hawtrey 1913:14-15]. It is a store of uncertain value because it can be hoarded until needed for use in exchange. Importantly, paper money provides a level of predictability which would be unattainable if certainty in nominal value was lacking. The ability to effectively organize activities is the use par excellence of paper (nominal) money; it has no other economic use.

Paper money, because of the general acceptability of its assured nominal value which is referred to as the purchasing power of money, is a reference frame for measuring the exchange 
ratios of commodities. At each given point in time, the purchasing power of available commodities or set of exchange ratios (the relationship of one commodity to another and each to every other) is a function of the demand and supply conditions. While the exchange ratio (purchasing power) of each and every commodity is subject to change, the nominal value of money is constant. Unequivocally, the quantity of commodities that can be purchased is a function of time and place.

In the social evolutionary process, nominal (paper) money has replaced commodity money ${ }^{9}$ to overcome the inherent limitations of a commodity money. ${ }^{\mathbf{1 0}}$ Two peculiar problems are introduced when a commodity serves as money: (1) depending upon alternative uses for that commodity, its exchange relationship with each and every other commodity is subject to change; and (2) in the case of metallic currency (gold and silver), the need for specialists in that commodity is created [Lees 1935:cii]. These two conditions impose two separate costs: (1) cost of acquiring the necessary information on the changing exchange relationships of the commodity [Bautier 1971:164,168,169], and (2) cost of determining the quality of the specific commodity-the commodity money being tendered in each exchange.

\subsection{Money: Its Relation to Credit and Its Measurement Function}

With an assured (certain) nominal value conferred upon it by official decree, ${ }^{\mathbf{1 1}}$ paper money is a medium of exchange, the general acceptance of which is based upon the full faith of the populace in the credit worthiness of the issuing authority. ${ }^{\mathbf{1 2}}$ Essentially, paper (fiat) money is credit! According to Steuart (1767:406-407): "Symbolical or paper [fiat] money is but a species of credit; it is no more than the measure by which credit is measured. Credit is the basis of all contracts ... He who pays in paper puts his creditor in possession only of another person's obligation to make the value good to him: here credit is necessary even after the payment is made." (Emphasis added.) The following passage provides added insight into the foregoing statement:

Credit causes a greater circulation of cash and replaces cash in circulation. The extent to which these two means of exchange - money and credit - increase together shows that they render the same services, and when the functions of either one are enhanced the other is invoked into more lively activity. This condition does not contradict the fact that in many instances credit makes cash superfluous [Simmel 1978:194]. 
It should be evident, based upon the functioning of the economy, that a credit economy is characterized by a cash-flow process [Salvary 1989:98-99].

Furthermore it is economically critical that the role of credit and its impact not be overlooked. In a study of business cycle creations [Salvary 1991:451-457], the behavior of business firms and that of consumers were utilized to provide support for the existence of three cycles: an investment cycle, a consumption (durable goods replacement) cycle, and a credit cycle. Hall [1986:239,254-255], sharing the view of a consumption cycle, concluded that shifts in consumption expenditures are an important source of overall economic fluctuations. Friedman [1986:437], not advocating a credit cycle, maintains that money is incapable of providing an explanation of economic fluctuations, and that the credit system can provide a better gauge than money of business activities and accordingly of economic fluctuations.

As documented [Salvary 1996:457,458 Tables 6 and 7], "Customers are granted credit to the very limit of their credit capacities. Their repayments are scheduled for several years into the future. Except for basic consumption goods and services, this condition produces a significant negative impact upon future consumption. It is only when the debts of consumers have been reduced considerably that another wave of frantic expansion can be experienced [Salvary 1996:451.” Inescapably, after a certain period of economic expansion, consumers' credit capacity becomes strained - credit is saturated. Since consumption is a function of disposable income and consumers' credit capacity, the credit cycle emerges because the system can only accommodate so much growth in a certain period of time. Consumer credit outstanding, at the end of 1975 in the U.S., amounted to $\$ 168.7$ billion; and at the end of June 2005, consumer outstanding credit increased to $\$ 2,145.6$ billion [Federal Reserve Board 2005].

Invariably, societal efforts - the introduction of money as a measuring device and the evolution of a monetary economy - are directed to the reduction of the cost of transactions. These efforts explains why society has adopted paper (fiat) money which is cost efficient [Alchian 1977]. With the introduction of nominal money, the two types of cost associated with commodity money are eliminated. The cost of transactions is reduced by paper money because it eliminates: (1) the transactions' vulnerability to the fluctuations in the exchange ratio of the commodity money and (2) the monitoring cost of the quality of the commodity money. Nevertheless, nominal (fiat) money is not a costless agent; it is available only at a cost: the rate 
of interest, which is determined by supply and demand. The cost associated with paper money, which is de facto the cost of credit, is derived from the intensity of its use [Salvary 1993:159].

\section{5 - ACCOUNTING IN A MONETARY ECONOMY}

In a monetary economy, a continuous spot market for money exists and the liquidity cost and the carrying cost of money is zero. In this setting, money, "a vehicle for transferring purchasing power over time," is an "unchanging [nominal value] standard against which all other durables [readily reproducible capital goods] and titles to capital goods and debt contracts can be measured [Davidson 1972:62-64]." The investing and financing commitments of organizations are for a forward market with business firms pursuing profits and governments and philanthropic organizations seeking balanced budgets. While Figures 2 and 3 [Salvary 1981:144] illustrate segments and functions of the socio-economic system, for simplicity the rest of this paper will focus primarily on the business organization - the firm.

Figure 2: Segment 1 - Commodities Market

\begin{tabular}{|c|c|c|c|c|}
\hline$\frac{\text { Entrepreneur/ }}{\underline{\text { Manager }}}$ & $\frac{\text { Contractor/ }}{\underline{\text { Employee }}}$ & Investor & Consumer & Government $* *$ \\
\hline $\begin{array}{l}\text { Operator } \\
\text { of }\end{array}$ & $\begin{array}{l}\text { Provider } \\
\text { of }\end{array}$ & $\begin{array}{l}\text { Financier } \\
\text { of }\end{array}$ & $\begin{array}{l}\text { User of } \\
\text { Business }\end{array}$ & $\begin{array}{l}\text { Provider } \\
\text { of }\end{array}$ \\
\hline
\end{tabular}

* Pension funds, estates and trusts are subsumed under the title of business.

** Philanthropic organizations are subsumed under the title of government.

\section{Figure 3: Segment 2 - Capital Market}

Suppliers of Capital

Individuals

Business*

\section{Users of Capital}

Individuals

Business

Government**

* Pension funds, estates and trusts are subsumed under the title of business.

** Philanthropic organizations are subsumed under the title of government. 
The firm is an institutional arrangement brought about by the adaptive process of society. As per Boulding [1950:106,112] and Georgescu-Roegen [1971:216], the firm is concerned with the accumulation of a stock of money. Hence, the production process in a surplus-oriented money economy is motivated by monetary exchanges to accumulate money (store uncertain purchasing power). While a monetary economy enables storing of purchasing power in nominal terms, accounting provides the means by which the firm's management can control resources, plan the activities of the firm, and ultimately evaluate the end results of such activities.

From an informational perspective, organizational activities involve the adoption of one alternative among several and information based on the adopted course of action is furnished in financial statements. Traditionally, financial reporting focuses on what has occurred, no reference is made of the possible consequences if other rejected courses of action had been adopted. It is financial accounting information that enables decision-makers to ascertain the financial position and profitability resulting from the course of action actually undertaken in light of the then existing circumstances. If financial reporting is to provide factual data that captures the effects of the actual sequence of events, then financial accounting standards must focus on organizations' actual operating plans within the context of the existing credit economy as characterized by a cash-flow process and not a cash basis focus. [Salvary 2006b:101-102]

Within the institutional arrangements of a monetary economy, the members of society as participants assume a variety of roles. The institutional arrangements and participants are presented in Table 2. Diagram 1 is a simple illustration of the mechanics of a monetary economy.

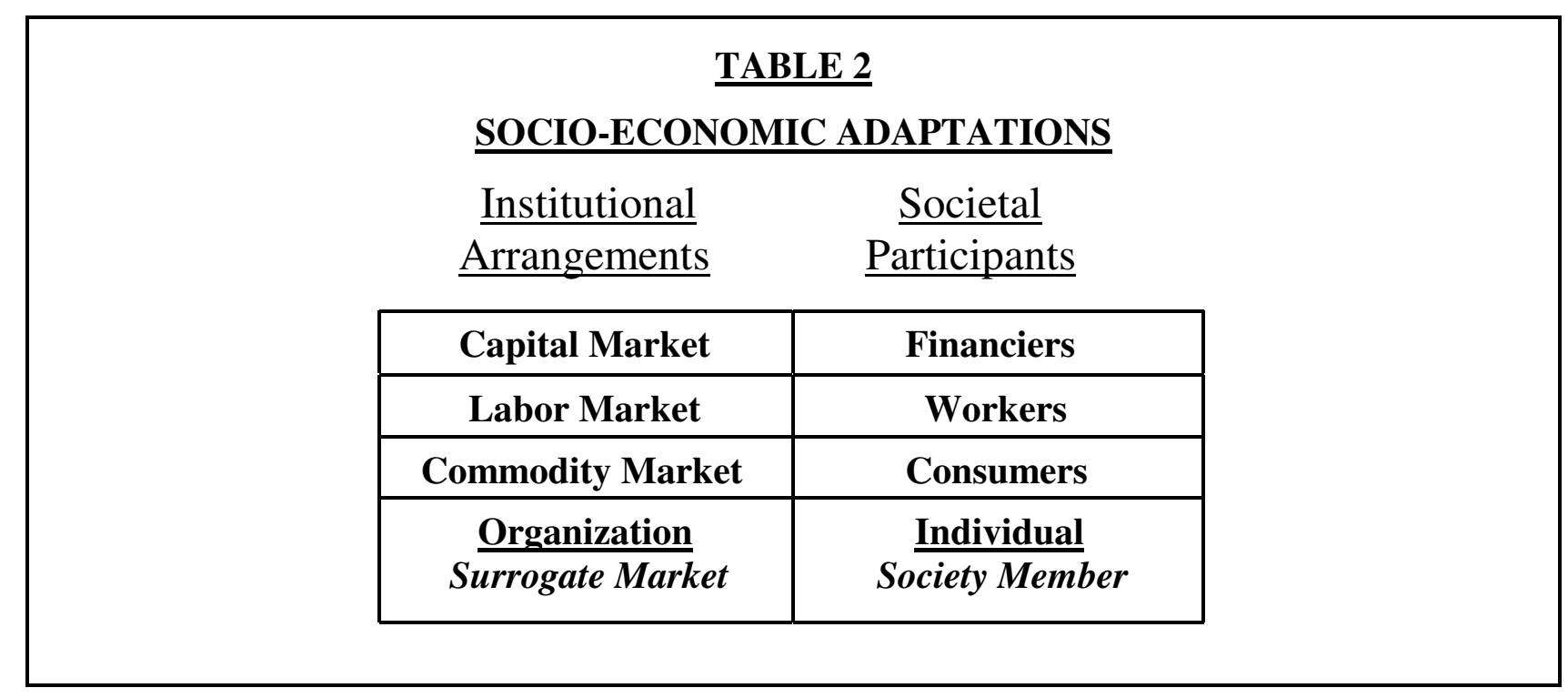




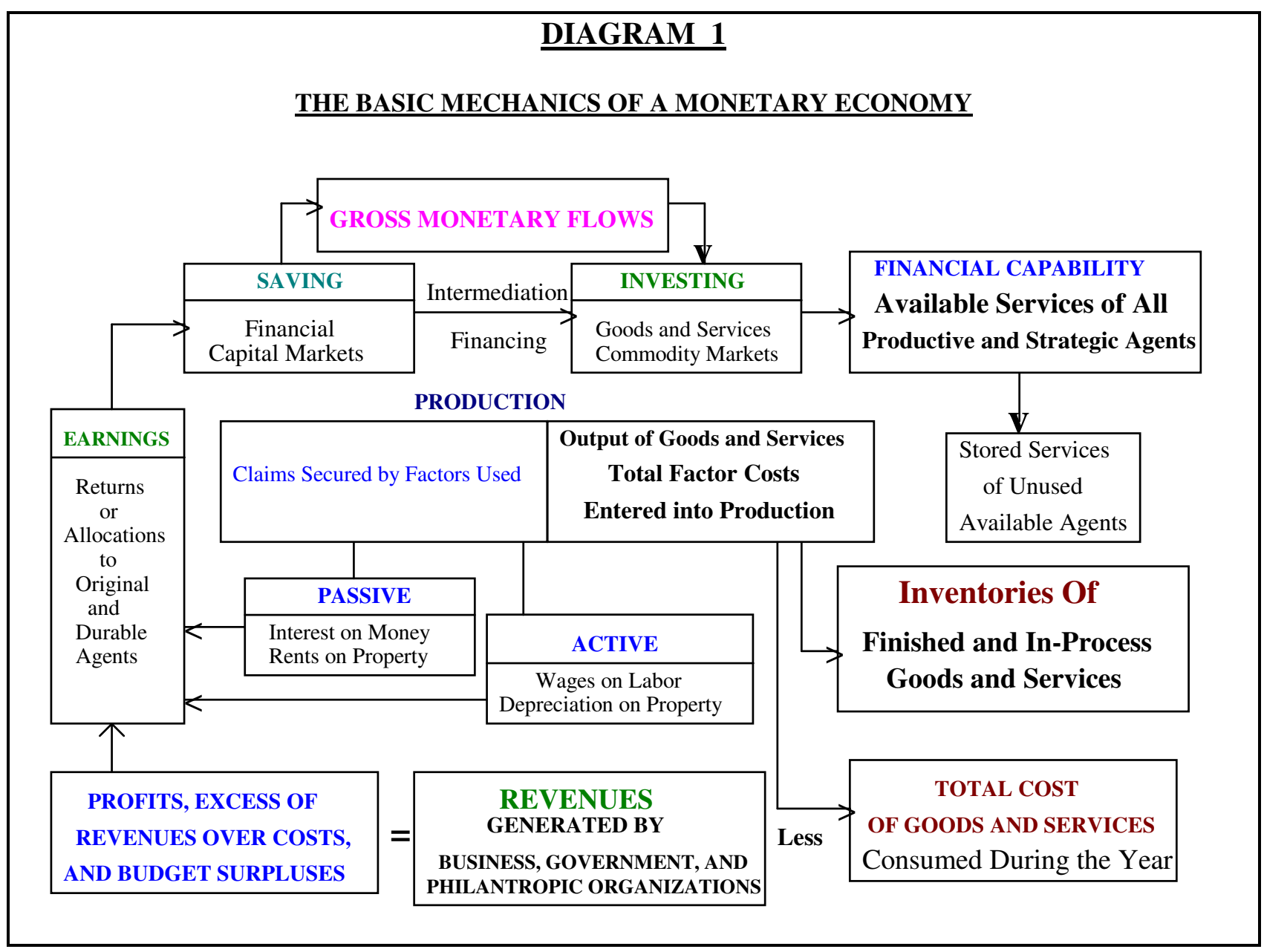

Profit or loss (budget surplus or deficit) emerges as a result of producing (providing) goods and services. The difference between inflows of money into the commodity market (representing consumption decisions - the revenue stream from consumer demands) and the portion of the nominal money investment in the production of goods and services consumed by consumers for a given period constitutes profit or loss. The firm enables society to maximize its welfare by reducing uncertainty and increases efficiency in its input and output decisions. In the social setting, the firm (as a surrogate market) is a vehicle for long range planning.

\subsection{The Firm and Long Range Planning}

Money is entrusted to the firm to bring about the desired results which is to be measured in money terms. It is by means of money capital that the firm is enabled to engage in long term planning. In this manner, uncertainty is reduced and efficiency is increased. Invariably, the firm 
has a long run plan. It does not have the luxury of exiting and re-entering the market place at will. Operating in the presence of uncertainty, the firm's decision to invest is with the full understanding that in the short-run there may be negative returns, but over the life of the investment the desired rate of return (more or less) will be achieved. Nevertheless, firms may fail to deliver desired results. Rising factor costs may render a firm ineffective, in the sense that it cannot transfer the additional costs to end consumers, taxpayers, and donors.

On one hand, when conditions reveal that in the long run the organization's costs of operation (OC) will be greater than the organization's revenues $(\mathrm{OR})$ : $\{\mathrm{OC}>\mathrm{OR}\}$, then at best the organization will terminate certain operations/services; at worst it will discontinue operating. The inability to transfer to consumers rising factor costs does contribute to the failure of some organizations. On the other hand, when individuals' cost of needs (ICN) are greater than individuals actual earnings (IAE): $\{\mathrm{ICN}>\mathrm{IAE}\}$, they are forced to reduce their consumption. This condition is the rising cost of living, which is identifiable as inflation.

Contrary to the position - based upon physical capital maintenance - which maintains that management uses old cost for pricing decision [Hughes, Liu, and Zhang 2004:731; Niehans 1978,127; Parker 1975, 512-524], management does act in anticipation of price level changes [Bergfield 1981:42]. The budgetary process, as described above, reveals that organizations' production decisions are based upon expected revenue being able to cover total costs - fixed and marginal costs. As factor costs are changing, so do organizations' output costs. These new costs as planned for and incurred constitute the investment costs to be recovered. Accordingly, adjustment of the actual money value of an exchange transaction as recorded, to show the alleged impact of inflation on the business organization, would alter the signal generated by the system. This condition would materialize because the relative measurement capacity of the rate of return on nominal money invested would be altered [Salvary 1993:170]. The rationale for this position is simply that:

. . . [P]hysical productivity measures do not reveal consumer preferences, and it is the rate of return on nominal money which provides a clear indication of the efficiency of the financial flow system. . . . Output decisions in a money economy are conditioned by the rate of return on nominal money invested and not by physical factor productivity. The rate of return over cost (and its special variant - the marginal rate of return over cost) is a factor which influences the rate of interest [Fisher 1930:176]. The firm's utility function and 
the utility function of the individual members of society are expressed in a money metric. . . . . . . [I]n a money economic system, the investment decision is indifferent to the physical quantities, but highly sensitive to the rate of return on nominal money invested. While the two systems (the physical and the financial) are linked; they are not interchangeable. [Salvary 1998a:310]

\subsection{The Relevance of Nominal Money Investment and Accounting Income}

Due cognizance must be given to the fact that with measurements based upon concepts corresponding with the structures and regularities of the system (the nature of the firm, the role of time, planning, investment plans, contracts, the means for the settlement of obligations, the posting of nominal money prices, etc.) from which it abstracts, financial accounting provides an observational report. The measurement property identified in the cash flow process engaged in by the firm is recoverable cost [Salvary 1992]. The accrual basis financial accounting captures the cash flow process which involves: (a) financing, (b) investing - acquisition of productive assets, (c) transformation of inputs into the consumable product, (d) distribution of the product, (e) realization of vendible value (a receivable established), and ends with (f) collection of the realized value. (This process description is modified for financial and service enterprises.) [Salvary 2004:13-14]

Unmistakably, the firm is engaged primarily in a nominal money augmenting process. That is, financial resources are stored in the form of nonmonetary assets and released in the revenue generating process at amounts greater (or possibly less) than the earlier stored amounts. This process is a cash flow process. The actual cash flow processes of firms are measured by financial accounting. Firms execute their plans and the consequences as measured in nominal money terms constitute economic reality [Salvary 1996/1997:8].

Accounting theory incorporates the effect of supply and demand operating in the financial and commodity markets. These forces affect the ability of the entrepreneur to recover money outflows over the long run and not the short run. All business organizations do not have the identical cost (supply) curve. Given the dynamics in the capital and commodity markets, at certain prices some business organizations will be forced out of the industry because their supply curves will effectively eliminate them from competing in the market environment [Von Mises 1949:286-291; Kaldor 1966:34-50; Marshall 1927:808]. The departure of those business organizations will be precipitated by the inability to recover money invested. 
It must be emphasized that, when costs (money invested) are deemed unrecoverable, the obsolete process is terminated. Even though the business organization is still solvent, it concedes that the investment is lost [Wessel 1972:10-13; Forbes 1979:348-352]. The investment cost is written down to its salvage value or zero [Business Week 1972:104-105; Berkeley 1971], whichever is appropriate in the then existing conditions of the capital and commodity markets.

\section{6 - THE BASICS OF THE CAPITAL AND THE COMMODITY MARKETS}

Apart from being differentiated by time, the capital market (a spot market in which financial claims and savings change owners) is quite distinct from the commodity market ( $a$ forward market in which goods and services are produced for delivery). The commodity (forward) market, in which specific factors of production are valued, is an extemporaneous process; values in this market are arrived at from a compounding process. The capital (spot) market is a continuous process of revised expectations of projected earnings and future cash flows to be generated in the commodity (forward) market. In the capital (spot) market, which is an instantaneous pricing process, prices are established based upon the discounting of future expected amounts. As the production process (the fruition of goods and services) moves closer to the delivery period, the compounding period lengthens in the forward market and the discounting period shortens in the spot market.

Although, the commonality of time seems to be present in both markets, it is the element of time which differentiates the capital (spot) market from the commodity (forward) market. The spot market discounting process merely uses the time frame for instantaneous price formation - merely an adjustment for the time value of money; but the forward market depends on time for the execution of production plans--time is the critical factor. The spot market permits risk-sharing arrangements; thus instantaneous price formation is critical for the efficient functioning of this important market.

The IASB's intent to mandate the use of current value as evidenced by IFRS3 Business Combinations, IFRS4 and Insurance Contracts [Deloitte IAS PLUS 2004], and International Accounting Standard 39 - Financial Instruments: Recognition and Measurement [European Central Bank 2004] as the basis for financial reporting is based upon the implicit assumption that the firm operates within the framework of a spot market. Unequivocally, the recommended approach - current value - ignores the role and importance of the commodity (forward) market. 
[Salvary 2006a:64] The use of a capital (spot) market model (a short period) for financial reporting is subject to the following major criticism:

The short period point of view, however, does not pick out a short period for particular attention - a procedure which would indeed enable us to consider the alternatives of using factors inside and outside the short period. It supposes, instead, that a short period exhausts the whole of the future that has to be considered so that there is nothing outside it. It might perhaps better be called the shortsighted point of view, which so narrows the horizon that no possible uses of a factor outside the short period can be seen. [Lerner 1939:563] (Emphasis added)

Current market value, demand and supply prices, are quantities which refer directly to a point in time. Whereas, terms such as income, revenue, returns, expenses, savings, and investments pertain to a time period for which they are calculated. These items are reported at a point in time, which is the end of an operating period [Myrdal 1939:45]. To embrace market value, as the basis for financial accounting information (hence financial reporting in the socioeconomic system), would present serious problems for managerial performance and assessment.

The spot market (current market value) approach to valuation virtually excludes the time element from the firm's operations; hence, human planning and action is precluded. This condition is so because the system encompassed by spot markets is a static system. The other ramification of a static system is that money is reduced to a veil under which transactions are executed. However, money is not a veil [Newlyn 1962:92], it is a dynamic factor which extends the production process and provides for an efficient means of allocating goods and services. Also, the investment process (acquisition of the factors needed for the production of goods and services) imply human action and human action is a function of time. No time, then no action! The above discussion can be appreciated in light of the following passage:

Action is change, and change is in the temporal sequence. . . Action is to make choices and to cope with an uncertain future. ... In order to grasp the function of entrepreneurship and the meaning of profit and loss, we [economists] construct a [static] system from which they are absent. . . . [as] a tool for our thinking. It is not the description of a possible and realizable state of affairs. . . . The various complementary factors of production cannot come together spontaneously. They need to be combined by the purposive effort of men [women] aiming at certain ends and motivated by the urge to improve their state of satisfaction. 
Money is necessarily a 'dynamic factor'; there is no room. . . for money in a 'static' system. But the ... notion of a market economy without money is self contradictory. ... . In ... [the] frame [of a static system] there is in fact no longer any action....

[D]ealing with the uncertain conditions of the unknown future... . speculation. . . is inherent in every action, and. . . profit and loss are necessary features of acting which cannot be conjured away by any wishful thinking. [Von Mises 1949:249-251] (Emphasis added.)

For the concept of the flow of time to have meaning, then the determination of profit can take place in one direction only - the firm buys/produces and then sells. In this process, the revenue generated less the cost of generating the revenue equals profit or loss. At the end of each operating period, the firm can: (1) return all funds to the suppliers of finance; (2) replace the goods and services sold in an attempt to repeat or better past performance; or (3) acquire more finance to extend/expand the operations. The firm operates over a distinct time period and not at a point in time. To ignore this reality is to replace a dynamic occurrence with a static situation [Salvary 1998b:34-44]. Evidently, the problem that confronts accounting standard setters is the perceptual field in which spot (capital) and forward (commodity) markets coexist.

\subsection{The Perceptual Field}

In Diagram 2, measurement occurs in the forward/commodity market (an extemporaneous

\section{DIAGRAM 2}

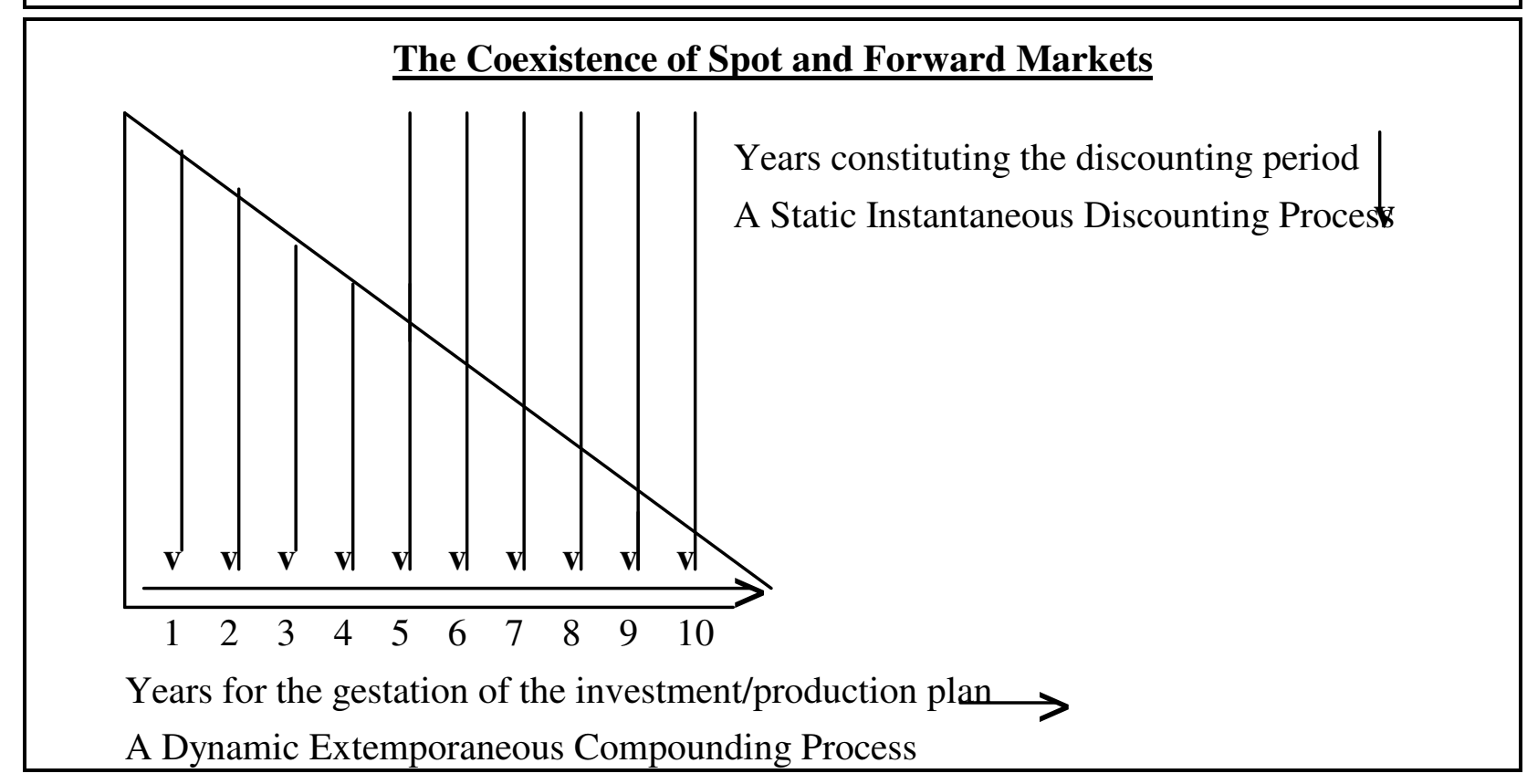


process) and the pricing of financial instruments occurs in the spot/capital market (an instantaneous process). The vertical lines represent instantaneous pricing in the spot/capital market and the horizontal line represents the production process in the forward/commodity market. Market values of the multiplicity of securities that are priced in the capital market are identifiable with the vertical lines. Committed finance by firms in the commodity market, that is captured in financial statements, correspond with the horizontal lines.

The association, arising from the interrelatedness of the two sets of lines, does not form a basis of cohesion--they are not bound together; that is one valuation is not an adequate

expression of the two separate and distinct, though inter-related, phenomena. ${ }^{\mathbf{1 3}}$ Essentially, the pricing process in the spot/capital market for future expected future cash flows is not identical with the measurement process via financial accounting involving committed finance in the forward/commodity market.

\subsection{Market Value Versus Committed Finance}

From the standpoint of accounting theory, the spot market arrives at current values of assets, whereas, financial accounting tracks down committed finance. Market values are signals which are important for the decision-making process [Salvary 1989:50-52]. For example, market values of firms' share prices are public information, and extrapolations can be made from financial accounting information to evaluate the value of those shares. In other words, the value of the firm--based upon outstanding shares--is a function of the spot/capital market; whereas, financial accounting measurement - of the realization of committed finance in the forward market - enables capital market participants to assess the relative merits of existing spot/capital market values.

There is no denying that investors need more information to enable a more effective spot/capital market valuation. Securities investors need and "should require the publication of financial, marketing, and production policy information [including forecasted financial data in] . . . financial reports," [Logue and Merville 1972:44] to reduce their uncertainty about the future. To assume that there is no news (information) in annual financial statements, because they are not a predictive device [Ball and Brown 1968:159-178], ${ }^{\mathbf{1 4}}$ ignores/overlooks the purpose of those statements. The contents of those statements provide the means by which the financial community and other interested parties can judge management's ability to manage under conditions of uncertainty. 


\subsection{The Standard by Which to Judge Management's Ability}

The assessment of management's performance requires the use of ex post (realized) models as characterized by financial accounting. Such models describe the fate of all current outputs; that is the actual conditions (prices, wages, interest rates, etc.) which obtained in the time sequence are delineated [Eucken 1951:553-554]. According to Von Mises [1949:211]:

There are monetary units and there are measurable physical units of various economic goods and of many - but not of all - services bought and sold. But the exchange ratios which we have to deal with are permanently fluctuating. There is nothing constant and invariable in them ... They are historical event, expressive of what happened once at a definite instant and under definite circumstances. (Emphasis added)

Management can only be judged on an ex post basis (on what has been done) and not on a current value basis (on the basis of changing market values). The ex post information contained in financial statements provides feedback on successes and disappointments. Management's planning is on an ex ante basis and it is financial accounting information, which is ex post, that enables management to plan a future course of action. Invariably, management uses planning models--managerial accounting--in performing its tasks; such models are concerned with the discovery of solution values for equation systems (optimization) with a futuristic perspective. Based upon Figure 1 and Table 1 it is clear that, owing to the time perspective, the characteristics of financial accounting and managerial accounting are essentially different.

\section{7 - CHARACTERISTICS OF FINANCIAL AND MANAGERIAL ACCOUNTING}

To ensure conceptual clarity in this area of the exposition, five concepts are used: (1) the state of being (current existence); (2) static theory (historical condition) - identified with financial accounting; (3) the possibility of becoming (potential for future change); (4) dynamic theory (fluidity) - associated with managerial accounting; and (5) the communication of knowledge (information dissemination - financial reporting) [Salvary 1985:44].

Financial accounting, which captures and describes an entity's state of being; is embedded in a static theory. Managerial accounting, which deduces from the given state of being and projects the possibility of becoming, is grounded in a dynamic theory. Herein, performance measurement captures a state of being and decision-making projects the possibility of becoming. Logically, a state of being (the present) is not the possibility of becoming (the future) and vice- 
versa. So, when change is imminent, one cannot look at a description of a particular state of being and expect it to be a projection of the possibility of becoming. Effective control over the entity requires having a sound description of the state of being which is the point of departure for an assessment of alternatives culminating in a projection of the possibility of becoming.

As revealed in Figure 1 and Table 1, two separate space/time relationships comprise the phenomenal observations (abstractions of reality) of financial and managerial accounting. On one hand, the economic space occupied by the firm in time $t$ is captured in financial accounting information--the sphere of historical financial reporting. On the other hand, the economic space to be occupied by the firm in time $\mathrm{t}+1$ is a projection of managerial accounting information--the sphere of prospective financial reporting [Salvary 1998b:322].

Financial accounting (description/explanation of behavior) provides information that captures the firm's foundation (asset, liability, and equity structure) for the planning process in managerial accounting [Yu 1976:47]. The foundation (the statement of financial position/ balance sheet) reveals the limitations imposed upon the organization. Managerial accounting (predictions/projections of behavior) provides evaluations of the existing foundation to determine the feasibility of desirable plans of future action. The plans (shaped by decision models) focus on the organization's operating possibilities, so that the limitations and the plan are interlocking [Barriere 1961:143; Kaldor 1961:150; Lamberton 1965:116].

Financial accounting information provides a measure of current earnings and residual financial commitments. In a unidimensional measurement, financial accounting portrays the manner of an organization's past behavior, but it does not project the future. The financial condition and strategic posture of an organization are historical facts. While an organization's past cannot be changed, information derived from financial accounting (as input into managerial accounting) enables the organization to plan for change in the future.

In accordance with static theory, financial accounting focuses on measuring a type of kinetic financial energy. The measurement focus is upon the organization's risk exposure assets vis-a-vis liabilities, existing investment projects, and cash recovered and recoverable cash from established commitments. Financial accounting generates information from the perspective of a conceptual framework (a firm sequence of thoughts entailing classification and measurement), but does not evaluate this information. It organizes perception into a cohesive 
system and the relationships identified are of prime significance--essentially semantic, the articulation of all its parts introduces an element of endogeneity.

Operating from dynamic theory, managerial accounting focuses on measuring a type of potential financial energy--organizational capability given internally and externally available resources. Conditions under which an organization had performed in the past are subject to change. Accordingly, managerial accounting (with an ex post focus in the form of variance analysis) has primarily an ex ante focus. It transforms static observations into a wide range of prospective considerations reflecting various amplitudes in a discrete manner. The information, which it generates, is in anticipation of probable future changes and their effect on the investment strategy of the entity: the deployment of resources and the method of operations.

Managerial accounting generates information from the perspective of cognitive models by decomposing the system into its component parts and focusing on the ability of the system to make change--a sub-system approach [Salvary 1979:375;1985:39-41]. Any relevant external factor can be considered enabling a syntactic relationship, thus an element of exogeneity exists. Managerial accounting focuses on prescriptions/predictions which enable management within a 'signal matrix' to evaluate considered alternatives/signals [Salvary 1985:49-50]. The term 'signal matrix' is characterized by a statement of available alternatives and their consequences given differing possible states of nature. A series of prices are presented along with a series of capital expenditure outlays, which in combination would provide a series of alternatives to be considered. While an array of alternatives is derived from this maze, each bit of information has relevance only in the context of a specific plan.

It is important to note that while accounting information is an essential input into the decision-making process, such information is of necessity modified by other information inputs of the decision-maker's model [Ford and McLaughlin 1976; Hughes and Downs 1976; Lorie and Hamilton 1973:154; Wright 1964:72]. Despite being highly informative, accounting information is not a complete representation of the organization. Motivated by purpose, both branches of accounting deal with abstractions of reality--partial observations.

\section{8 - ABSTRACTIONS OF REALITY: EXPLANATION AND PREDICTION}

An abstraction of economic reality which is embedded in the financial accounting framework is the measurement of profits derived from the cash flow process [Salvary 2006b:90]. 
In this cash flow process, which is the central feature of a monetary economy, resources are contracted for in nominal money terms producing financial quantity flows throughout the economy. Subsequent to the implementation of investment plans, cash flow measurement ensues. Basically, production and consumption involve the storing of financial inputs in various forms at one moment and the subsequent release of those financial inputs in the form of cash at another moment. Cash flows are directly related to money committed to investment plans and the ability to recover such monetary amounts upon the gestation of those plans. While the factual/realized (ex post) data are recorded by financial accounting, management planning (ex ante) data for cash flows are derived from managerial accounting. According to Eriksson [1954:341-342]:

[T] he formation of economic data in the real world can only be explained historically. The data need classification into data from the point of view of the individual unit, the economy as a whole, planning data [managerial accounting data], and ex post data [financial accounting data]. The economist, when formulating economic problems and abstracting and analyzing their significant characteristics, is bound to have to deal with the conditions on which the course of economic events depends.

In spite of functional differences among the various monetary economic systems, the fundamental law of recovery--recovery prevents/precludes loss--constitutes the basis of the financial accounting measurement rules and enshrines recoverable cost as the unique measurement attribute/property in financial accounting. This law of recovery, which encompasses the aforementioned accounting laws - productivity, capitalization, continuity, and bankruptcy [Salvary 1989:33-36], is operational in all models of investment and is most obvious in the payback model [Salvary 1992:236].

Risk sharing and decision making are inescapable features of any economy in spite of their variations. As indicated in Diagram 3 [Salvary 1984:40], for risk sharing purposes, recoverable cost - with the qualitative characteristics of reliability and neutrality - is the measurement attribute that captures the investment decision as made and the consequences of that decision as reported in annual financial statements. For decision making purposes, relevant cost - with the qualitative characteristics of relevancy and neutrality - is the planning attribute that is essential to the development of the investment opportunity set as presented in managerial accounting analyses and budgets. Basically, financial accounting and managerial accounting constitute the totality of the empirical science of accounting. 


\section{DIAGRAM 3}

THE DUALISTIC MODEL IN ACCOUNTING: THE TOTALITY OF ACCOUNTING

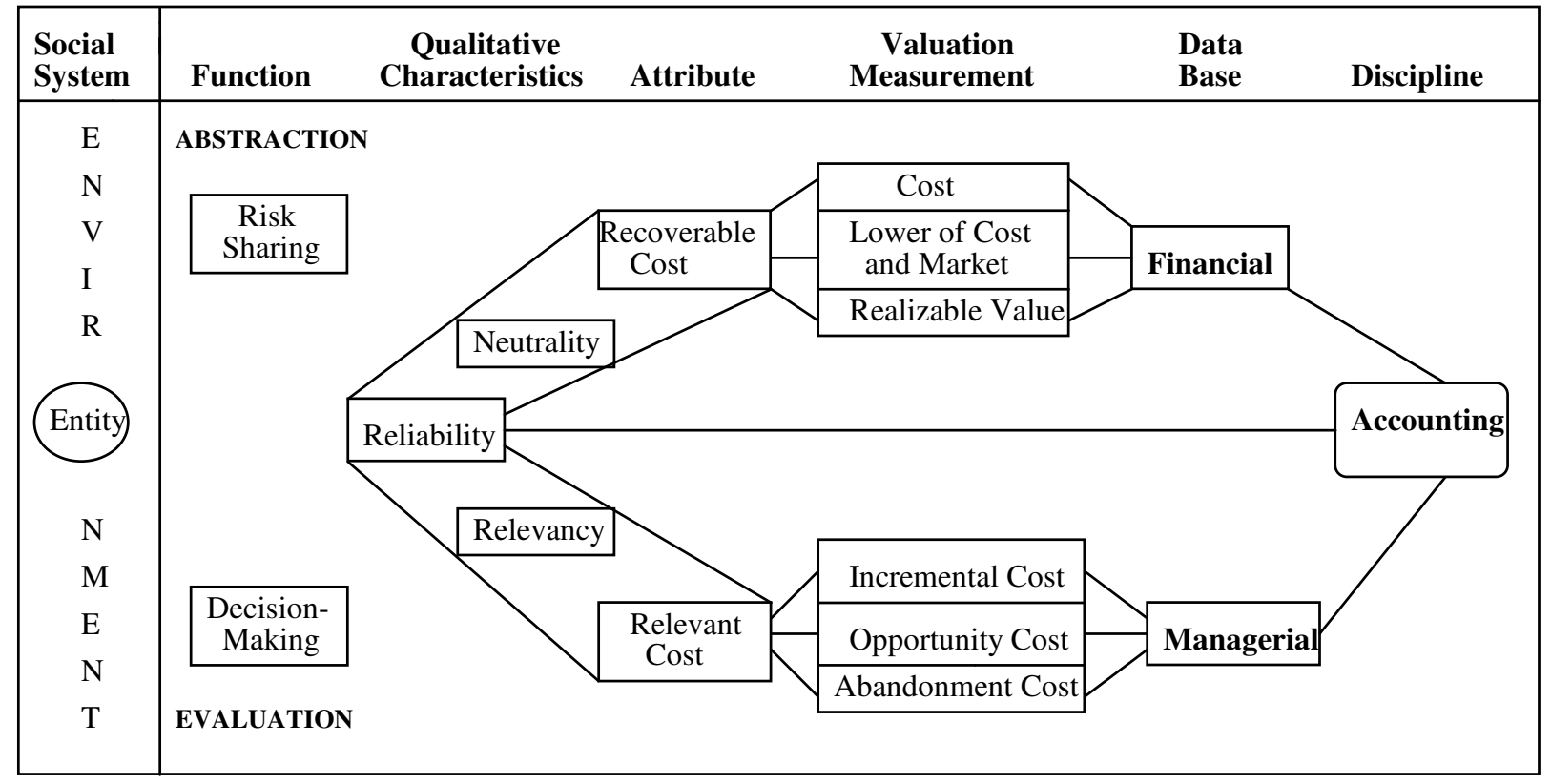

By design, financial accounting identifies the resources available for use and captures the historical performance of an organization. The historical data of financial accounting constitues a platform for planning in the decision making process - i.e, the prediction/projection of future occurrences (evaluation of possibilities) via managerial accounting to enable effective managerial control. In this setting, the balance sheet in financial accounting lends itself to a dual interpretation. The balance sheet at the end of the accounting period is both an ending and a beginning balance sheet. It is an ending balance sheet for the period which has just ended and the beginning balance sheet for the period just beginning.

The preceding discussion reintroduces the recurring issue of the coexistence in space and time which can be appreciated given the following passage:

Things co-exist in space because they are present to the same perceiving subject and enveloped in one and the same temporal wave. But the unity and individuality of each temporal wave is possible only if it is wedged in between the preceding and the following one, and if the same temporal pulsation which produces it still retains its predecessor and anticipates its successor. It is objective time which is made up of successive moments. The lived present holds a past and a future within its thickness. [Merlau-Ponty 1962:275] 
The magnitudes in the ending balance sheet is based upon an ex-post concept - the firm's realized financial strength through periodic conversion of assets (non-monetary assets into money and the subsequent acquisition of expected profitable non-monetary assets). This ex-post concept is based upon looking at the balance sheet as the consequence of prior decisions--a backward looking view. Given its expectation for the future, to deal with the uncertainty facing the firm, the beginning balance sheet would be analyzed via managerial accounting processes an ex ante analysis. In this manner, fundamental to decision-making, the firm's operating limitations inherent in the liquidity aspects of the enterprise are assessed.

Essentially, the ending balance sheet accommodates an assessment of past performance. The beginning balance sheet serves as the starting point for current decisions to be made--a forward looking view. Unequivocally, the decision-making process is a forward looking view dictated by expectations and uncertainty.

\section{9 - EXPECTATIONS AND UNCERTAINTY}

In accounting theory, the enterprise is be deemed to be either a "going concern" or a "liquidating concern". The basis for accepting that the enterprise is able to operate as a "going concern" rests upon reasonable evidence rather than mere expectations. To be deemed a going concern, a firm must have: (1) committed finance (money) to its operation; (2) implemented investment plans, and (3) those plans provide for the recovery of the money (finance) invested. Furthermore, an unbroken connection must exist between the investment plan (financing, production, distribution, and collection) and the recovery plan (revenue stream to be generated from the investment) [Salvary 1989:35-36].

Given that the firm is operating in an atmosphere of uncertainty, the evidence is tentative. However, it is based upon the guarded expectation that prices prevailing in the future will be sufficient to permit the recovery of all outlays made and being made in the current period. If such prices are expected to fall then accumulated cost has to be written down to reflect those expectations. For financial reporting purposes, when the conditions for a "going concern" are satisfied, the use of the estimated recoverable cost (invested resources/committed finance expected to be recovered) approach is justified [Salvary 1985;1989;1992]. In the absence of such conditions, the firm is de-facto a "liquidating concern" and the liquidation or exit value approach to measurement for a liquidating concern is applicable. 
In general, an organization's operation is a long-term proposition. Careful planning and a realistic planning horizon are vital for success. It is only in the long term that the organization will be judged to be a success or a failure. A firm can stick to its production plan as a going concern or sell its physical facilities as a liquidating concern at the prevailing exchange price-the current value; whichever course of action it chooses renders the other irrelevant. The firm's performance can be measured and judged only in terms of the alternative chosen. The question as to which course of action (alternative) should be chosen is a managerial accounting decision problem and not a financial accounting reporting problem.

In financial accounting, the current prices of factor inputs are recorded at the time transactions are consummated. While all prices become past prices and past prices do not enter into current decisions, financial accounting is concerned with outlays, and the ultimate recovery of such outlays. The mission of financial accounting is to reflect the decision as manifested in the financial outlays. As noted by Von Mises [1949:205,287,291]:

An act of exchange is neither preceded nor accompanied by any process which could be called a measuring of value. Values and valuations [nominal money prices and capital market prices] are intensive quantities [properties of abstract space] and not extensive quantities [properties of Euclidean space].

In the market economy all those things that are bought and sold against money are marked with money prices. In the monetary calculus, profit [in financial accounting] appears as a surplus of money received [money claims secured] over money expended [money obligations incurred]. Profit and loss can be expressed in definite amounts of money. It is possible to ascertain in terms of money how much an individual has profited or lost. However, this is not a statement about his individual's psychic profit or loss. It is a statement about a social phenomenon...

An entrepreneur can make a profit only if he anticipates future conditions more correctly than other entrepreneurs. Then he buys the complementary factors of production at prices [costs - anticipated recoverable money outlays] the sum of which is smaller than the price [revenue - realized money claims] at which he sells the product.

From the standpoint of accounting theory, past prices neither govern nor relate to the decision in question. Implicitly from an accounting perspective, Haavelmo [1960:167-170,172173] cautioned that there is clear distinction between a capital loss (arising from a change in the interest rate) and a loss resulting from a reduction in profit (due to a change in product/service price). The entrepreneurial adjustment to these two situations are entirely different. 
The institution of contracts in money terms may introduce a new kind of income element in the calculations of the entrepreneur, the possible gains or losses due to the changes in the money value of capital. This means that capital may be held for speculative purposes at the same time as it serves as a factor of production.

It is essential to realize that these effects cannot be "deflated away" by reckoning in constant dollars, or the like. Actual or prospective changes in money value of capital enters in a very real way into the investment decisions and may affect the volume, as well as the structure, of capital accumulation. (Emphasis added.) [Haavelmo 1960:156]

Financial accounting, at the beginning of each period, focuses on owned resources, obligations, and outlays made by management. At the end of each period, financial accounting reports on the resources owned, obligations, and the recovered and recoverable amounts of the earlier outlays. The end results for each and every period, as reported in the financial statements, permit an assessment of management's ability to manage in the face of uncertainty. Financial accounting reports provide the means by which management's ability can be and should be judged. The approach in financial accounting is in line with Marshallian analysis [Marshall 1927:311], which is expounded below:

$$
\begin{aligned}
& \mathbf{O}=\mathbf{R} \\
& \mathrm{O}=\text { Money outlays } \\
& \mathrm{R}=\text { Money recoveries discounted over the recovery period } \\
& \text { at the planned rate of return. }
\end{aligned}
$$

The complete mathematical formulation is as follows:

$$
\text { (1.1) } \mathbf{O}=\sum_{n=1}^{k} R_{n} /(1+r)^{n}
$$

Where:

$\mathrm{r}=$ rate of return required given the risk inherent in the industry

$\mathrm{n}=$ number of periods constituting the recovery period

While $\mathrm{O}$ is a given datum, $\mathrm{R}$ is extrapolated from time and is subjected to change; such change as anticipated is provided for in the decision. However, given price level changes, it is argued that nominal money calculations constitute an inappropriate measure of the discharge of the stewardship function of management [e.g., Hughes, Liu, and Zhang 2004:731; JofA 1982:90-92; Niehans 1978:127; Parker 1975:512-524]. As a consequence, there is concerted 
effort to reform financial accounting information to account for the effect of price level changes. Additionally, due to the lack of isomorphism between financial accounting information and securities market values, the relevancy of financial accounting information is consistently challenged [Barth, Beaver, and Landsman 2001; Brennan and Connell 2000; Hackney 1999].

\section{0 - THE DRIVE TO REFORM FINANCIAL ACCOUNTING INFORMATION}

The desire to reform financial reporting is due to the perennial concern for measuring the impact of inflation (price level changes) on the business enterprise. The Accounting Standards Steering Committee of the Institute of Chartered Accountants in England and Wales (ASSC), on

May 14, 1974, issued SSAP 7 which required a supplementary Current Purchasing Power Statement [Sandilands Committee 1975]. Likewise, the Financial Accounting Standards Board, in 1979, issued Statement of Financial Accounting Standards (SFAS) 33, which provided for constant dollar and current cost accounting information.

The recent reform requires current value accounting, which is mandated by the International Accounting Standards Board (IASB) [IAS 40: Investment Property; IFRS4: Insurance Contracts; IAS 39: Financial Instruments]. The thrust of this reform is a revival MacNeal's [1939:102,147,181] view that economic values/current market values should be used as the basis of financial accounting measurement in lieu of actual transactions determined values.

\subsection{The Price Level Change/Inflation Issue}

Proponents of accounting for price level changes maintain that money loses value, therefore the use of nominal money as a measure of organizational performance is seriously flawed. The view is held that the use of nominal money as the measurement unit in financial accounting causes the erosion of capital to escape the attention of business managers [Mosich and Larsen 1982:497-498; Business Week 1979:108-112; Chambers 1975:58,62; Morgenstern 1963:66]. It is contended that this condition needs to be addressed since it is responsible for the inability of business firms to replace assets internally [Niehans 1978:127; FASB 1979:para.124].

The requirements of the Statement [SFAS 33] are expected to promote a better understanding by the general public of the problems caused by inflation. Statements by business managers about those problems are unlikely to have sufficient credibility until financial reports provide quantitative information about the effects of inflation [FASB 1979:ii]. 
However, reality prevailed. In March 1980, the ASSC issued SSAP 16 to replace SSAP 7 which was then rescinded. In turn, SSAP 16 was rescinded in 1986 by the ASSC. In 1984 with SFAS 82, the constant dollar component accounting information of SFAS33 was withdrawn by the FASB. With the issuance of SFAS 89 in 1986, what was left of SFAS 33 was withdrawn due to users' views and empirical studies which concluded that the information generated lacked usefulness. In addition, according to many respondents, it appeared that managements and investors had information better than or different from that required by SFAS33, therefore even an improved set of disclosures might not be useful. Furthermore, some respondents believed that other factors are more important in investment decisions than information on changing prices, such as the inescapable effects of interest rates on monetary assets and liabilities or the opportunity and ability to raise capital to finance the replacement of productive capacity by means of external sources [FASB 1986:paras.117,118,124,130; McDonald and Morris 1984].

Evidently, the allegation, that an organization fails to maintain its economic capital (physical productivity capacity) because accounting information is based upon outdated costs, ignores the temporal difference between an existing investment and an investment decision yet to be made. The role of anticipations is confused with that of actual accomplishments. The following passage cautions against the admixture of anticipations and accomplishments.

The current supply of a commodity depends not so much upon what current price is as upon what entrepreneurs have expected it to be in the past. It will be those past expectations, whether right or wrong, which mainly govern output; the actual current price has a relatively small influence. This is the first main crux of a dynamic theory; and it marks the parting of the ways. [Hicks 1946:117]

To correct the alleged deficiency in financial reporting due to inflation, it has been suggested [SSAP7 (1974); SFAS33 (1979)] that the firm's operating performance should be reported using constant dollar and/or current cost accounting. In this regard, due cognizance must be given to the fact that the maintenance of physical productive capacity - economic capital maintenance is only one possibility inter alia of management's decision [Logue and Merville 1972]. Furthermore, shareholders cannot be construed to be concerned with economic capital maintenance [Hunt 1967:83] and the least to be concerned would be creditors. The decision to maintain economic capital or return funds to shareholders in the form of dividends is a managerial decision, which would be reflected in management's dividend policy [Olsen 
1967:31]; it is not a concern of financial accounting. Financial accounting is concerned with measuring the outlays made by management and the amount of such outlays recovered and recoverable. Such information reflects on management's ability to manage under uncertainty.

The firm is faced with factor costs, which are incorporated into the price of its output. Since everyone's income and assets do not rise proportionally with increases in the general level of prices, it is primarily the individual wage earner, as an end consumer, that is faced with the problem of inflation - the rising cost of living [Fuller 1980:8]. The end consumer absorbs the rising factor costs or do without. Arguably, any measure of the impact of inflation should focus on how end consumers are affected. Yet, the reformers want to ensure the availability of internal financing for future asset replacement, which may or may not occur. In this setting, information generated to measure the impact of inflation on the business enterprise would be irrelevant and un-interpretable since the recommended solution to the problem of future financing needs is to alter the measurement of financial performance

The reformers' position confuses or fails to distinguish/differentiate between measurement of past performance (within the framework of financial accounting: ex post measurement) and financing planning (within the framework of managerial accounting: ex ante projection) (See Table 1). Unequivocally within the context of financial planning, the concern for future financing is sound, yet under no circumstances should the concern for self financing infringe on the measurement of financial performance [Salvary 1998c:311]. In this regard, the distinction between ex post measurement and ex ante projection has been given full and explicit recognition by the Institute of Chartered Accountants in England and Wales in 1949 with Recommendation N. 12 and reaffirmed in 1952 with Recommendation N. 15:

[A]ny amount set aside to finance replacements (...fixed or current assets) at enhanced costs should not be treated as a provision which must be made before profit for the year can be ascertained but as a transfer to reserve. [Sandilands Committee 1975:107]

\subsection{The Current Market Value Issue}

Based upon the sentiment that the market provides the assessment of investors, the IASB requires capital market values and not transaction-based measures to be used in preparing financial accounting information. Support for the IASB's view on the deficiency in accounting can be found in Smirlock, Gilligan, and Marshall's [1984:1054]: "Future firm's rents [earnings] 
... will be [are] appropriately capitalized by an efficient market ... Relying on capital markets to value rents avoids or substantially mitigates most of the shortcomings inherent in accounting profit rates [accounting measurement of profits]."

While the capital market does arrive at a value for a firm's security, it cannot measure the cash flow that is or has been generated by the firm in the earnings process [Salvary 2003:159]. It should be obvious that signals generated by a signaling system--the capital market--must not be confused with information depicting an operating system--the firm [Salvary 1989:50-52]. Thus, the use of current market value as the basis for accounting valuation has to be addressed in context of measurement theory and the roles of the commodity and capital markets.

Fundamentally, financial accounting measurement is a financial product costing process related to the production plans of firms operating in the commodity market. Measurement of current cash flows generated by a firm establishes the cost of that firm's financial product. In the capital market, accounting earnings (i.e., estimates of future earnings) and accounting residual value (i.e., current residual cash commitments--the estimated recoverable cost) are priced as a unit; hence, valuation in the capital market is a financial product pricing process. Since the financial product pricing is the valuation of estimated future cash flows expected to be generated by a firm's production plan and any expected residual cash value, it should be clear that the pricing process is (and has to be) different from the costing process [Salvary 1998b:28].

Despite the fact that a firm's profit is relatively constant, the price of its security is highly variable. This condition holds because the valuation process in the capital market, which facilitates transfers of titles to claims, captures changes in financiers' beliefs about risks and liquidity. Two elements of market pricing/valuation (the discount rate and the investors' planning horizons) are accountable for this condition; they are highly sensitive to money market conditions and personal expectations. The discount rate is sensitive to changes in the interest rate which reflect changing conditions in the availability of money. The investors' time frame/planning horizon is sensitive to investors' liquidity considerations [Salvary 1998b:39].

Furthermore, being that investors' expectations are at times highly optimistic or highly pessimistic, investors' projections of future earnings - which are based upon the firm's current period's profit - are subject to optimism or pessimism. This factor causes the capital market values to be ephemeral in nature. Evidently, it is fair to conclude that the inclusion of changes 
in market value will contaminate the financial accounting measurement of firms' profits. Therefore, it is more likely than not that the contaminated information, when furnished to the market participants, will produce distorted market pricing of some firms' securities. Such an effect can be expected due to the causative order of association between market value and accounting profits. Chronologically, market value is arrived after the projection of future profit; such projection occurs after measurement of current period's profit has been reported.

In accounting, measurement of profit does not begin with market value as a given. Market valuation begins with the release of financial accounting information. Conceivably, the inclusion of market volatility in financial statements will disrupt the accounting measurement process and distort the portrayal of a firm's current period profit and financial position. This condition will obtain due to an ill-conceived association between the market valuation process and the measurement of a firm's profit as generated in the cash-flow process [Salvary 2006b:113-114].

\section{1 - THE ACCOUNTING MEASUREMENT PROCESS ${ }^{15}$}

The measurement process in accounting involves two distinct types of calculus: an ex-ante and an ex-post. Financial budgets reflect an ex-ante calculus, which entails prospective calculation; while financial statements reflect an ex-post calculus, which involves retrospective calculation. Except for costs that are not subject to change (sunk costs), the budget provides for future price level changes. The financial statements reflect the actual costs of all items including the changes in the costs of those items that were subject to change. The cash flows in the ex-ante/projected and the ex-post/accomplished calculi are depicted in nominal terms and not in "real" terms. Furthermore, all obligations in general, even if calculated in "real" terms, are reported and settled in nominal terms.

On the assumption that the budgetary process involves some type of maximization which is expressed in financial terms, then to maximize "real" dollars, it would be necessary to maximize nominal dollars. "Real" dollars are a function of nominal dollars, because it is only nominal dollars that circulate. Given the foregoing, the firm attempts to maximize that which has general acceptability--nominal money. Apparently, it is reasoning along this line of thought, that led Samuelson [1961a:215] to maintain that it is doubtful, despite the importance of the index number, that Pigou (the eminent welfare economist) seriously would "suggest that the thing to be maximized is the money value of output deflated by an ideal index of prices." 
As necessitated by action(s) contemplated and consequence(s) anticipated, financial budgets focus on money inflows and outflows. As anticipated, changes in prices of new inputs are provided for as they involve cash outflows in the budget period. Those costs, that are paid for in advance in order to minimize cost, involve no cash outflow in the budget period; they are sunk costs and are not subject to price changes. Likewise, there are some new costs involving cash flows that are for services governed by fixed price contracts; these contracts are designed to shield/preclude those services from unanticipated price changes in the budget period.

Prior to transition from a subsistence to a money economy, a value measure for calculating did exist, but the price level problem did not. It emerged with the introduction of a money form - a medium of exchange, the generally acceptance of which: (1) permitted a uniform command over the purchasing power of goods and services, (2) enhanced specialization, and (3) increased efficiency of the economic system [Hendrickson 1970:29-30]. Since firms do not produce a balanced basket of goods, money eliminated holding commodities by providing the means by which labor services for money wages are traded for commodities [Leijonhufvud 1981:68-70].

In view of the foregoing discussion, accounting has to recognize the nature of a money economy as differentiated from a subsistence economy, the role of contracts, and the unavoidable time gap between production and ultimate disposal.

\subsection{Subsistence Economy vs Money Economy}

Accounting measurement, in a subsistence economy, is in purely physical terms, e.g., bushels of wheat, tons of iron, and heads of pigs [Sraffa 1960]. Hence, a necessary condition for maintaining the existing steady state is the replacement of the physical inputs. If there is to be growth in the system, output must exceed input.

The situation is different in a money economy - labour services are exchanged for money and not traded for goods and services. Since nominal money is the only item in a money economy that has general acceptability [White 1984], nominal money is the unit of measure. Accordingly, contracts for goods and services are stated in nominal money terms.

\subsection{Contracts}

Unmistakably, the role of contracts and the role of the capital market are fully recognized in financial accounting. It is accepted that contracts are used in an attempt to control input cost-- 
cost minimization. Cost control is critical to profit maximization, to achieve that end contracts are used. Individual savings are channelled into investment opportunities by means of the capital market. In order to store services via contracts, money capital is necessary; accordingly, the entrepreneur resorts to the capital market.

Money enables/accommodates the storage of services which are critical to production and distribution decisions. When expenditures on stored services (durable agents-machines, etc.) are made, the money outlays remain money-capital [Ashley 1912:482-483]. Each such expenditure is a fixed contract for services to be released by usage in the future with the passage of time. Subsequent to the investment in capital and vendible goods, for fruition to occur a period of time has to elapse - the unavoidable time gap. During such time the nominal amount of the investment is consumed in the form of depreciation and cost-of-goods sold.

\subsection{The Unavoidable Time Gap.}

Since phenomena succeed one another instead of taking place all at once, the accountant expressly accepts the proposition that: "Time is a device to prevent everything from happening

at once." ${ }^{16}$ The firm, in a market economy in which prices are expressed in nominal money terms, is confronted with planned outputs or inputs over time in response to certain nominal money price expectations [Lutz 1951:15]. The following traits are present in a money economy: (1) The investment decision - money is committed to an investment based upon actual input costs (in period t) and expected output prices (in period $t+1$ ). The expected nominal money return is the difference between the two money values. (2) The planning process - the input costs and output prices are the fundamental ingredients of possibly a linear programming model that is utilized by management. (3) The resource allocation process - a sum of money is committed (in period t) to a plan of action. (4) The plan's fulfillment - the sum of money (more or less) resurfaces periodically in $\mathrm{t}+1$ or $\mathrm{t}+\mathrm{n}$ - the end of the expected time.

The firm has a special role in society and its accountability to society is a significant and fundamental responsibility. In this regard, the following section provides a brief insight on the firm and explains why the accountant measures business profits in nominal money terms.

\subsection{The Firm's Social Responsibility: Accountability}

To accommodate the changing needs along society's evolutionary path, the firm emerged 
as a conduit for social exchanges. For an economic system to be efficient, it is imperative that there be some form of organizing production in an efficient manner. While the firm emerged to satisfy that requirement, the firm per se is not essential to the economy. Owing to the continuous monitoring of relevant prices in the various markets for factors, the firm emerged to overcome the burdensome and grossly inefficient cost of continuous renegotiations. It is reasonable to conclude that society can and will replace the firm with any means which can be developed to handle that function better than the firm [Buchanan 1940].

In accordance with Copeland's [1937:129-132] analysis, business firms and final owners of wealth are the transactors in the economy. Households, governments, and not-for-profit organizations are the final owners of wealth. Business firms, being merely intermediaries in accommodating social exchanges, are factored out in a national balance sheet. As stated earlier, society established the firm in order to maximize the use of its human and material resources [Coase 1937:392]. Consequently, the firm is merely a conduit through which money flows as a result of the given economic arrangement.

Generally, in advanced economies only the means of payment constitute capital, and only money is the means of payment [Schumpeter 1939:42,110,129; Neibyl 1946:19]. To coordinate the factors of production, the firm receives capital - essentially money savings - from investors/financiers [Buchanan 1940:33-34]. The capital supplied by financiers is in exchange for claim instruments (financial assets). The money savings as received are invested in acquiring the factors of production which constitute the investment (real assets). According to Hollis [1934:127], real assets are money in use. Apparently, the function of monetary calculation is to render recognizable the path that leads to the desired goal with the least expenditure of means [Von Mises 1960:146].

"Both the firm and the market are merely innovations on the part of society in its neverending quest for its efficient functioning. While money is a device for measuring social exchange, the firm and the market are the vehicles through which exchange is effected." [Salvary 1998c:239] Being that the allocation of resources (materials and human) within and among firms involves money as an agent, society needs to determine the efficiency of time and other resources management. This condition gives rise to the need for a measurement in the use of money. Hence, an accountability emerges to recognize: (1) the risk-sharing arrangement 
among suppliers of money; (2) the surrogate-market nature of the firm; (3) the element which constitutes capital: money and credit; and (4) the extent of goal achievement - the measurement of profit or loss for the business organization and the level of effectiveness and efficiency in the use of resources by governmental and philanthropic organizations.

\subsection{Governmental and Philanthropic Organizations}

In this exposition, society is deemed to be involved continually in a very extensive investment process. The social investment process entails the acquisition of knowledge and the dissemination of such information to the members of society. The intent of such activity is to bring about a general awareness to minimize the costs of social exchanges. The many sub-level organizations that have emerged in society are continuously undertaking investments. Whether undertaken by the municipality, the non-profit hospital, or the business enterprise, investments by any component of society constitute the observable accounting phenomena.

Unequivocally, society is continually extending the borders of our knowledge and accommodating new forms of organization. Being welfare maximizing, by means of various types of organizations, society attempts to maximize the social welfare while minimizing transaction costs. Transactions and other events - engaged in by business firms, government agencies, or philanthropic organizations - are the means by which investments are undertaken.

Since its inception, accounting, while serving all sectors within any socio-economic system, is dispassionately free from attachment to any economic system [Salvary 1985:8]. Through adaptation (to a system's structure and modus operandi), accounting serves each and every socio-economic system. In modern times, the economies of most (if not all) nations consist of four basic sectors: business, government, philanthropy, and households. While the four sectors are serviced by organizational accounting with a measurement focus of financial capital maintenance, the nation state is serviced by national/social accounting with a measurement focus of physical capital maintenance [Salvary 1989:59-60]. Sections 12 discusses the differing perspectives of national and organizational accounting.

\section{2 - NATIONAL (MACRO) VS ORGANIZATIONAL (MICRO) ACCOUNTING ${ }^{17}$}

Measurement is different in each of the two levels - national (macro) accounting and organizational (micro) - of accounting, owing to differences in their underlying functions. For 
national accounting, the function of financial accounting is the determination and distribution of the wealth of the nation [Copeland 1937:6]. The main objective in organizational accounting is the determination and control of flows of the allocated amounts of the unit of accounts within and among the various organizations. Failure to give due cognizance to the subtle but significant difference between the functions of the two levels of accounting does lead to troublesome misunderstandings.

An insightful and explicit recognition of the functional difference exists in the literature; however, the terms used in that work are slightly different from those used above. Goldsmith [1950:24] posited that the common term "accounting" is more appropriately termed social accounting, and identified two levels: national business accounting and national economic accounting. An explanation of the difference between the two levels of accounting follows:

The periodic inventory may have one of two functions: it may be designed to show the amount that can be realized if the business is liquidated or sold or regarded as a statement of unrecovered cost. The first lacks meaning if applied to a community. The economic equipment of a community, particularly one as large as a nation, can neither be sold as a whole nor liquidated piecemeal. To measure the unrecovered cost of a community's physical assets is possible and not without interest, but it is not the primary purpose of the periodic economic inventory, in business parlance, the balance sheet of a community. That purpose rather is to determine the total assets and the total net worth of all economic units that make up the community, primarily to the end of analyzing asset composition, wealth distribution, and claim and liability interrelations... [Goldsmith 1950:24-25] (Emphasis added)

Misunderstandings in the fields of accounting and economics, on the nature and functions of these two levels of accounting, are reflected in the debate on the maintenance of physical capital versus maintenance of financial capital. The following factors provide the basis for the difference between national (economic) accounting and organizational (business) accounting:

(1) Society is a natural state of nature; whereas, the firm is an artifice of society (Stauss 1944:112-127). (2) The resources of a society are allocated by that society to segments within that society. (3) The discipline of accounting emerged to facilitate the control and planning of the allocation of resources among segments of society: macro-level accounting. (4) The separation of the ownership from the use of resources was made possible and to great human advantage by the accounting process. (5) The firm emerged as a result of social advances (a social evolutionary process), and necessitated a new accountability: micro-level accounting. [Salvary 1990:222] 
At the time of Adam Smith, David Ricardo, and John Stuart Mill, the difference between micro- and macro-level accounting was recognized. Yet, such difference was not explicitly addressed until the enactment of the British Companies Act in 1844 when financial reporting for enterprises became a required phenomenon. It is only then that the distinction between accounting for a nation and an enterprise was fully explicated. The difference between the society and the firm is made clear by Von Mises [1949] and Goldsmith [1950]. The firm can sell all its resources to other firms or individuals, society cannot. For society, maintaining real/physical capital is a truism; for the firm, the maintenance of physical capital does not apply.

National income (Y) is a distribution of the Net National Product, which is a summation of the payments for factors (materials, wages, rents, interest, and profits); it is a macro-level concept. Equation 1, which is in static equilibrium, reflects the aggregation of micro-units.

\section{1. $\quad \mathrm{Y}=\mathrm{C}+\mathrm{I}+\mathbf{E x}+\mathbf{G}$}

$(\mathrm{C}=$ Consumption $; \mathrm{I}=$ Investment $; \mathrm{Ex}=$ Exports $;$ and $\mathrm{G}=$ Government Expenditures $)$

Equation 2, which is in dynamic disequilibrium, reflects aggregation of revenues (R) and expenses (E) at the micro/organizational-level.

\section{2. $\quad \mathbf{R} \geq \mathbf{E}$}

Essentially, the sum of all compensation $(\mathbf{E})$ to all factors used by the firm can be equal to, greater than, or less than the firm's revenue $(\mathbf{R})$, the value of its output. By adding the variable $\mathbf{P}$ (profit) or $\mathbf{L}$ (Loss) - a residual amount - to equation 2, equality is achieved.

\section{3. $\quad \mathbf{R}=\mathbf{E}+\mathbf{P}(\mathbf{L})$}

The emergence and adherence to two different concepts of capital maintenance are necessary owing to the difference that exist between national/social accounting and organizational/business accounting. This is a necessary condition due to the fundamental difference between the nation/country and the organization/business. In the former, the focus is on costs versus benefits in optimizing social welfare (economic stabilization policies, etc.). In the latter, the focus is on nominal money revenues and nominal money expenses in achieving organizational goals (profitability, market penetration, etc.) [Goldsmith 1950:29-30]. The following section provides a cursory review of the two concepts of capital maintenance. 


\section{3 - CAPITAL MAINTENANCE CONCEPTS: NATIONAL VS ORGANIZATIONAL}

It is postulated that society is a natural state; whereas, the firm is an artificial device created by society in its never ending attempts to cope with changing conditions. In earlier times, all resources were owned by society. In its evolution, to enhance effective and efficient use of resources, society has devised various organizations to deal with the allocation and preservation of scarce resources.

\subsection{National/Social Capital Maintenance: Macro Accountability}

In economics, the primary theorem is that there are only two functions: production and consumption [Copeland 1937:4]. Given that production equals consumption in a steady state, to: (1) accommodate growth in population and (2) increase the standard of living, consumption has to be less than production. Unmistakably, in the national setting, physical capital maintenance is an imperative. Hence, in the calculation of national income, the replacement cost of worn out capacity is deducted from Gross National Product; only net investment is included therein.

Within the economic framework, depreciation is deemed to be savings which will be available for investment [Lacey 1952:6; Hicks 1965:304; Shackle 1968:70-71]. Based upon that premise, then depreciation allowances permit capital accumulation/formation at the national (macro) level [Hicks 1965:307]. According to Meade [1962:173-174], accumulated depreciation is a savings fund, similar to a sinking fund for asset replacement. With this view embedded in the national accounting measurement framework, the sentiment emerged within the economics community, that in the calculation of a firm's profit, depreciation should be similarly based on the replacement cost of the asset, rather than on the invested cost of the asset.

Given the "sinking fund" view of depreciation, the firm is seen as a source of financing capital formation. In many instance the revenues of some firms are not sufficient to permit them to recover their depreciation charges; depending on the situation some of those firms do go into bankruptcy. Given the foregoing, it is necessary to focus on how new businesses are financed. It is savings tapped from the capital market that enable the formation of new business firms.

\subsection{Organizational/Firm Capital Maintenance: Micro Accountability}

With the end of the feudal system, economic motives instead of political dicta determined 
the allocation of resources. The introduction of important institutional changes in society money (an allocative device) and the firm (a surrogate market) - were responsible for the improvements in the capital formation process. The change from a subsistence to a surplus economy did not change the initial proposition: production and consumption. Nevertheless, superimposed on the old structure is a new orderly arrangement which introduced new functions (groups): financing (financier) and organizing (entrepreneur). Consequently, new terms financing and investment did emerge. Essentially, financing is simply a restructuring of the former barter system, to create a much more efficient system: a money economic system. Economies of scale were made possible by means of investment which engendered specialization of the various social functions.

Money and the firm are adaptations by society to facilitate production and consumption [Copeland 1937:24]. The firms are conduits; they are systems of flows but are not stocks in themselves. Since the stocks are the resources of society, accounting for the firm is evidently different from accounting for national wealth [Prest 1969:293-300]

Transition from a subsistence economy to a money economy necessitated new institutional arrangements in the allocation of resources. Therefore, due cognizance must be given to two factors that were introduced: (1) a financial capital market and that which is to be maximized is money [Robinson 1962:8; Malthus 1827:60]; and (2) the accounting for: (i) financial capital secured in the money and capital markets, (ii) the amount of finance committed to investment projects, (iii) the amount of costs incurred in the implementation and operation of investment projects, and (iv) the results of the undertaking. Organizational operations involve the consumption of assets (resources). In particular, depreciation and cost-of-goods/services sold are measures of the amount of sunk cost and the amount of committed finance that have been productively consumed, but not necessarily recovered, in the period. The next section of this paper addresses the relationship or lack of relationship between depreciation and savings.

\section{4 - DEPRECIATION: AN EXPENSE VS. A SINKING FUND.}

In the accounting literature, depreciation is a measure of the cost of past service benefits; whereas, in the economics literature, it is a provision for the future cost of service benefits. For accounting purposes, depreciation is a measure of the amount of a fixed asset that has been consumed. In economics, depreciation is the means to provide for the cost of future asset 
replacement; it is a policy prescription as the following definition of depreciation reveals:

[A] measure of the consumption which must be foregone in order to replace those parts of the stock of commodity capital which are evaporating and which must be replaced if the stock is to continue its equilibrium growth. [Rymes 1971,1121]

As noted above, in economics, the concern is not for the cost of wear, tear, or obsolescence of an asset (past service benefits) in measuring past performance, but for the amount which has to be set aside to defray the cost of asset replacement (future service benefits). In accounting, depreciation is a process of decumulation. Whereas, in economics, it is a process of accumulation. A sinking fund, the provision for future financing of replacements, is used interchangeably with the term depreciation. While not making such a representation, it is possible that the sinking fund provision shown as a charge by Malthus [1819:269] has been assumed by other scholars (e.g. [Harrod 1973:61]) to be depreciation; thus, henceforth in the economics literature the term depreciation is considered as a synonym for sinking fund. Apparently, this view of depreciation - a financial provision for asset replacement - is shared by Keynes [1936:98-100]. Similarly, Evans [1969:332] and Baxter [1955:218] were concerned that there would be a "shortage of capital" for asset replacement as a consequence of inadequate depreciation provisions.

Undeniably, the primary objective in economic planning is to insure future equilibrium growth, in which case the physical replacement of depreciable capital assets is critical. Marshall [1927:350] noted that equilibrium growth is vital to society, but it is not applicable to the firm which is an institutional arrangement. The significance of the distinction noted by Marshall [1927:350] have been emphasized by Von Mises [1949:218, 252] and Goldsmith [1950:24-25] an individual (firm) can convert all of his/her (its) property into money, a nation (society) cannot. At this stage, it is necessary to probe at the source of the confusion due to the assumed sameness of national economic policy prescription and organizational financial accounting measurement.

\subsection{Possible Source of Confusion}

Indubitably, Ricardo's [1823:94-95] concern for replacing resources was national (social welfare) oriented and not enterprise oriented. Likewise, Mill [1830] was concerned with the preservation of society and was quite explicit in stressing the importance of the replacement of resources for national (macro) accounting: 
The net produce of a country is whatever is annually produced beyond what is necessary for maintaining the stock of materials and implements unimpaired, for keeping all productive labourers alive and in condition for work and for just keeping up their numbers without increase. [Mill 1830:88-89] (Emphasis added.)

The origin of the confusion in the financial accounting literature seemingly is due to the acceptance of Hicks' [1939] definition of income as a definition of business income. Hicks [1939] definition was related to Mill's [1830] definition - a national accounting definition and not an organizational accounting definition. It is important to note that Hicks [1942] made clear that the definition of income, which had been quoted quite frequently, was intended for social income determination. Also, the works of Leon Walras [1926], Alfred Marshall [1927], and Vilfredo Pareto [1927] reveal shifts in defining income from economic prescription in national/social accounting to performance measurement in organizational/business accounting.

\subsection{Economic Prescription Vs Performance Measurement}

In economics, given that replacement is a national economic imperative, the focus is on future service benefits as a measure for determining social income. In this regard, the accountant agrees with the future-service-benefits view, because it necessary for a proper determination of national/social income. However, since the social income view fails to give due cognizance to the difference between a sunk cost and a source of funds, in measuring business profits, the accountant views the past-service-benefits as depreciation.

For the purpose of national income, capital consumption signifies an amount that is necessary to replace what has been consumed. It is quite natural that when the term depreciation - (a micro/business concept) - is deemed to be synonymous with capital consumption (a macro concept) [Samuelson 1961b:33], one can readily understand how easy it is for confusion to arise from the subtle difference between the two concepts. For instance, though the term depreciation was not used by Mill [1844:221-223], he did refer to the annual wear and tear of durable machinery employed in business as partial consumption. Furthermore, since Mill [1844:223] maintained that it is necessary for the entrepreneur to be remunerated for the wear and tear of the entrepreneur's machinery (not for the physical replacement of machinery), the quasi-rent nature of depreciation can be inferred. This inference is due to the fact that the annual depreciation of an asset is comparable to the periodic payments on a long term rental (leasing) contract. Hence, depreciation, like any normal rent charge, is incurred as a result of the 
acquisition of a depreciable asset (capital good), which is acquired primarily to aid in the revenue (service benefit) generating process.

This condition that physical capacity replacement and physical capacity depreciation are two distinct phenomena - unrelated and separated by time - is explicitly emphasised by Domar [1957:95]. While with the passage of time, depreciation of a depreciable asset inevitably will occur; its replacement may never occur. Replacement of depreciable assets is a function of the investment decision which hinges on profit expectations and the availability of money capital.

\section{5 - CLOSING COMMENTS}

Accounting is a language of measurement which entails a decision problem: what is to be measured and how is it to be measured? Categorical reasoning, which consist of discreteness and finiteness of categories to components of the socio-economic system, is used in accounting. Accounting measures the effect of the phenomena as they exist, not in some physical constant but in value dynamics as captured by a nominal money measure.

In order to fulfill its function, accounting attempts to obtain a proper focus of the socioeconomic environment by drawing upon several disciplines, among which are economics, mathematics, psychology, and sociology. In this process, some terms used in accounting are also used by other disciplines. Unfortunately, when a term in another discipline symbolizes a different concept from that used in accounting, unnecessary debates ensue. While, terminological agreement between the disciplines is not necessary, there is a definite need for an understanding and an appreciation of the difference in use of term(s) in other disciplines.

\section{ENDNOTES}

1 For example around 425-421 B.C., one finds the "establishment of a reserve fund on the Akropolis." [Merritt, Wade-Grey, and McGregor 1939:127].

2 Some authors of this school of thought are identified by Goldberg [1971:33].

3 It provides a description of business conditions in Flanders in the Thirteenth Century.

4 For an extensive development of this point, see Zimmern [1961:302-303].

5 On the difference between hard money (coins) and fiduciary money (legal tender), see Jevons [1875,71-73, 190,229]. 
6 The importance of this institutional arrangement is stressed by Bernstein [1935:37-42] and Jevons [1875:194].

7 For instance, the "change from a money to a natural economy" occurred in the Merogivian Period (400-600 A.D.). "[T]he solidus survived as a money of account only," and payments were made in kind during the Carolingian Period (800-900 A.D.) [Deanesly 1956:126-140]. Also, in the British colonies in America (pre U.S.A.), "Transactions were reckoned in shillings and pence, but where coins were used they were commonly of Spanish and Portuguese origin" [Bernstein 1935:91].

8 Around 700 B.C. coined currency (gold and silver) emerged. At that time those who engaged in commerce and trade recognized the need for a common measure in bargaining to replace the time consuming effort of calculating the exact value of everything else. Axccordingly, coin (precious metals) currency established at a recognized value was issued for use in daily transactions. [Zimmern 1961,302-303].

9 The terms: paper money, nominal money, fiat money, and fiduciary money, are used interchangeably.

10 For some of the limitations of commodity money, see White [1984] and Mill [1844,113,295]. According to Sargent and Wallace [1983,170,171,173]: market inefficiency may be experienced when a commodity serves as money since the consumptive aspects of that commodity impinge upon its money function. In this latter regard, by releasing the commodity from its money function, fiat (paper) money provides an additional benefit to society [Sargent and Wallace 1982,1229,1231].

11 In the international money market, nominal money is a financial asset. Due to the need to settle trade balances arising from foreign trade, a demand and supply schedule for foreign currencies exists.

12 "China was the first country to issue bank-notes, and the founder of the Ch'in dynasty, Shih Huang Ti (249-202 B.C.) was the first to experiment with this form of currency. Continual wars had ravaged the land for many centuries, and the currency was totally discredited; illicit minting and adulteration of coinage caused violent fluctuations of prices, adding to the miseries of the poor, embarassing the Government and enriching speculators at no profit to the state" [Quiggin 1949,248]. Those conditions precipitated the need for the experimentation culminating with the formal adoption of paper money.

13 For the development of this point, see Merlau-Ponty [1962:14-16].

14 In spite of Ball and Brown's position, Hicks' [1973:35] dictum holds: "It is only on what has happened in the past that we have information."

15 This section is derived from Salvary [1990:218-219].

16 A quote attributed to Bergson [Robinson 1962:title page].

17 For an extensive development of this discussion, see Salvary [1990:219-220]. 


\section{REFERENCES}

Ackley, Gardner. (1983) "Commodities and Capital: Prices and Quantities." American Economic Review March:1-16.

Babbage, Charles. (1835) On the Economy of Machinery and Manufacturers. $4^{\text {th }}$ Edition reprinted 1971. New York: Augustus M. Kelley.

Barriere, Alain. (1961) "Capital Intensity and the Combination of Factors of Production." The Theory of Capital. Edited by F. A. Lutz and D. C. Hague. London: Macmillan \& Co. Ltd.; New York: St. Martin's Press.

Bautier, Robert-Henri. (1971) The Economic Development of Medieval Europe. London: Thames and Hudson, Ltd.

Bergfield, C. Daniel. (1981) Strategic Pricing: Protecting Profit Margins from Inflation. New York: Amacom, American Management Association.

Berkeley, Edmund C. (1971) "The RCA Computer Effort -- Common Sense vs. Catastrophe." Computers and Automation (November).

Bernstein, E.M. (1935) Money and the Economic System. Chapel Hill: Univ of North Carolina.

Boulding, Kenneth. (1973) "Economics and Accounting: The Uncongenial Twins." Financial Accounting Theory 1: Issues and Controversies. 2nd Edition. Edited by S. A. Zeff and T. F. Keller. New York: McGraw-Hill Book Company.

(1950) A Reconstruction of Economics. New York: John Wiley \& Sons. Inc. London: Chapman \& Hall, Limited.

Boyd, Edward. (1905) "Ancient Systems of Accounting." A History of Accounting and Accountants. Edited and partly written by Richard Brown. London: Frank Cass and Company Limited, 1905, 1st Ed. New York: Augustus M. Kelley Publishers, 1968.

Brennan, N. and Connell, B. (2000) "Intellectual Capital: Current Issues and Policy Implications." Journal of Intellectual Capital, Vol.1, No.3.

Brooklyn College. (1960) Source Book for History 1.1 - History of Western Civilization 1. Brooklyn, New York: Brooklyn College Press.

Burstein, M.L. (1963) Money (Cambridge, Massachusetts: Schenkman Publishing Co.

Business Week. (1979) "The Profit Illusion: With inflation and Obsolete Accounting, The Earnings Boom is Only on Paper." Business Week (March 19). (1972) "International Paper Responds to Treatment." Business Week (August 12).

Chambers, R.J. (1975) "NOD, COG and PUPU: See How Inflation Teases!" Journal of Accountancy (September) 
Cunningham, W. and McArthur, Ellen A. (1896) Outlines of English Industrial History. New York: Macmillan Company. London: Macmillan and Co., Ltd.

Davidson, Paul. (1972) Money and the Real World. New York; Toronto: John Wiley.

Deloitte IAS PLUS. (2004) Standards: IFRS 3 Business Combinations. History of IFRS3.

Eiriksson, Benjamin. (1954) Outline of an Economic Theory. Helgafell Publishing Company, Reykjavik, Iceland.

Eucken, Walter. (1951) The Foundations of Economics: History and Theory in the Analysis of Economic Reality. Translated from the German by T.W.H. Hutchinson. Chicago: University of Chicago Press.

European Central Bank. (2004) Fair Value Accounting and Financial Stability. Occasional Paper Series No.13. By staff: A. Enria, L. Cappiello, F. Dierick, S. Grittini, A. Haralambous, A. Maddaloni, P. Molitor, F. Pires and P. Poloni. http://www.ecb.int.

FASB. (1986) Statement of Financial Accounting Standards No. 89: Financial Reporting and Changing Prices. Stamford, Conn.: FASB.

. (1979) Statement of Financial Accounting Standards No. 33: Financial Reporting and Changing Prices. Stamford, Conn.: Financial Accounting Standards Board.

Federal Reserve Board. (2005) Principal Economic Indicators - Consumer Credit. Statistics: Releases and Historical Data. http://www.federalreserve.gov/Releases/.

Finley, M. I. (1973) The Ancient Economy. Berkeley; Los Angeles: Univ. of California Press.

Fisher, Irving. (1930) The Theory of Interest: As Determined by Impatience to Spend Income and Opportunity to Invest It. The Macmillan Company, New York.

Forbes. (1979) "All Numbers are Not Equal." Perspectives in Auditing. 3rd Ed. Edited by D. R. Carmichael and J. J. Willingham. New York: McGraw-Hill Book Co.

Frazer, William J. Jr. and Boland, Lawrence A. (1983) "An Essay on the Foundations of Friedman's Methodology." American Economic Review March:129-144.

Friedman, Benjamin M. (1986) "Money, Credit, and Interest Rates in the Business Cycle." The American Business Cycle: Continuity and Change. Studies in Business Cycles Volume 25. Edited By Robert J. Gordon. National Bureau of Economic Research. Chicago; London: The University of Chicago Press.

Fuller, Robert (1980) "Inflation: The Rising Cost of Living on a Small Planet." Worldwatch Paper 34. No City: Worldwatch Institute.

Georgescu-Roegen, Nicholas. (1971) The Entropy Law and the Economic Process. Cambridge, Massachusetts: Harvard University Press.

Goldsmith, Raymond W. (1950) "Measuring National Wealth in a System of Social Accounting." Studies in Income and Wealth Vol. 12. New York: National Bureau of Economic Research. 
Gordon, Barry. (1975) Economic Analysis before Adam Smith: Hesiod to Lessius. London: The MacMillan Press, Ltd., New York: Harper \& Row Publishers Inc.

Goldberg, Louis. (1971) "Varieties of Accounting Theory." Foundations of Accounting Theory. Edited by Willard E. Stone. Gainesville, Florida: University of Florida Press.

Gurley, John G. and Shaw, Edward S. (1960) Money in a Theory of Finance. Mathematical Appendix by Alain C. Enthoven. Washington, D.C.: The Brookings Institution.

Haavelmo, Trygve. (1960) A Study in the Theory of Investment. Chicago: Univ. Chicago Press.

Hackney, D. (1999) “Data Warehouse Delivery: The Hidden Jewel.” Data Management Review (October).

Haney, Lewis H. (1949) History of Economic Thought: A Critical Account of the Origin and Development of the Economic Theories of the Leading Thinkers in the Leading Nations. 4th Ed. New York: The MacMillan Company.

Hanson, Norwood Russell. (1969) Perception and Discovery: An Introduction to Scientific Inquiry. Edited by Willard C. Humphreys. San Francisco: Freeman, Cooper \& Co.

Harre', R. (1970) The Principles of Scientific Thinking. London: MacMillan and Co., Ltd.

Hawtrey, R.G. (1913) Good and Bad Trade: An Inquiry into the Causes of Trade Fluctuations. Reprint 1962. New York: Augustus M. Kelley Bookseller.

Hempel, Carl G. (1965) Aspects of Scientific Explanation and Other Essays in the Philosophy of Science. New York: The Free Press. London: Collier-MacMillan Limited.

Hendrickson, Robert. (1970) The Future of Money. Englewood Cliffs, NJ: Prentice Hall.

Hicks, John. (1973) Capital and Time: A Neo-Austrian Theory. Oxford: Clarendon Press.

. (1968) A Theory of Economic History. Clarendon Press, Oxford.

(1965) Capital and Growth. New York and Oxford: Oxford University Press.

(1946) Value and Capital. 2nd Edition. Oxford: The Clarendon Press.

(1942) "Maintaining Capital Intact: A Further Suggestion." Economica IX as cited in Readings in the Concept and Measurement of Income. Edited by R.H. Parker and G.C. Harcourt. Cambridge: Cambridge University Press, 1969.

(1939) Value and Capital. Oxford: The Clarendon Press.

Hiemann, Eduard. (1945) History of Economic Doctrines: An Introduction to Economic Theory. London; New York; Toronto: Oxford University Press.

Hudson, Michael. (1970) "A Financial Payments Flow Analysis of U.S. International Transactions: 1960-1968." The Bulletin Nos. 61-63. New York University, Graduate School of Business Administration Institute of Finance, March. 
Hughes, John; Liu, Jing; Zhang, Mingshan. (2004) "Valuation and Accounting for Inflation and Foreign Exchange." Journal of Accounting Research. Vol. 42 No.4.

Hunt, Pearson. (1967) "Profits from the Investor's Point of View." Profits in the Modern Economy. Edited by H. W. Stevenson and J. R. Nelson. Minneapolis: University of Minnesota Press.

Jevons, W. Stanley. (1875) Money and the Mechanism of Exchange. New York; London: D. Appleton and Company.

Johnson E.A.J. and Kroos, Herman E. (1953) The Origins and Development of the American Economy: An Introduction to Economics. New York: Prentice Hall, Inc.

Johnson, R.A.; Kast, F.E.; and Rosenzweig, J.E. (1967) Theory and Management of Systems. 2nd Ed. Fremont, New York: McGraw-Hill Book Company.

Jof A. (1982) "The FASB and Industry." Journal of Accountancy(October).

Kaldor, Nicholas. (1966) Essays on Value and Distribution. London: G. Duckworth.

(1961) "Capital Accumulation Production and Economic Growth." The Theory of Capital. Edited by F. A. Lutz and D. C. Hague. London: Macmillan \& Co., Ltd. New York: St. Martin's Press.

Lambert, Maurice. (1960) "La naissance de la bureaucratie." Revue Historique. Tome DCXXIV. (Translated by Dr. RoseAnne Martin, Canisius College).

Lauderdale, The Earl of. (1804) An Inquiry into the Nature and Origins of Public Wealth and into the Means and Causes of its Increase. Edinburgh: Arch. Constable \& Co., London: T.N. Longman \& O. Rees.

Leijonhufvud, Axel. (1981) Information and Coordination: Essays in Macroeconomic Theory. New York; Oxford: Oxford University Press.

Lerner, A.P. (1939) "From Vulgar Political Economy to Vulgar Marxism." Journal of Political Economy (August).

Lees, Beatrice A. Editor. (1935) Records of the Templars in England in the Twelfth Century: The Inquest of 1185 with Illustrative Charters and Documents. London: Oxford Univ. Press.

Lipson, E. (1959) The Economic History of England Volume I: The Middle Ages. London: Adam and Charles Black.

Lisle, George. (1900) Accounting in Theory and Practice. Reprint. Edinburgh and London: William Green \& Sons.

Logue, Dennis E. and Mervil1e, Larry J. (1972) "Financial Policy and Market Expectations," Financial Management.

MacNeal, K. (1939) Truth in Accounting. Philadelphia: University of Pennsylvania Press. London: Oxford University Press. 
Malynes, Gerard. (1622) The Ancient Law-Merchant. London: Adam Islip.

Malthus, T. R. (1827) Definitions in Political Economy. London: John Murray.

(1819) Principles of Political Economy: Considered with a View to Their Practical Application. First Ed 1819. Second Edition with considerable addition from the author's own manuscript and an original memoir. New York: Augustus M. Kelley, 1951.

Marshall, Alfred (1927) Principles of Economics. 8th Ed. London: Macmillan \& Co., Ltd.

Mattesich, R. (1964) Accounting and Analytical Methods: Measurement and Projection of Income and Wealth in the Micro- and Macro-Economy. Homewood, Ill: R.D. Irwin, Inc.

McNeill, William H. (1963) The Rise of the West: A History of the Human Community. Chicago; London: The University of Chicago Press.

Meltzer, A. H. (1983) "Interpreting Keynes." Journal of Economic Literature. March:66-78.

Merlau-Ponty, M. (1962) Phenomenology of Perception. Translated from the French by Colin Smith. London: Routledge \& Kegan Paul Ltd.

Merritt, B. D.; Wade-Grey, H.T.; and McGregor, M. F. (1939) The Athenian Tribute Lists. Vol. I. Published for the American School of Classical Studies at Athens. Cambridge, Massachusetts: Harvard University Press.

Mitchell, Wesley C. (1967) Types of Economic Theory: From Mercantilism to Institutionalism. Volume I. Edited with an introduction by Joseph Dorfman, New York: Augustus M. Kelley.

(1927) Business Cycles: The Problem and Its Setting. Foreword by Edwin F. Gay. New York: National Bureau of Economic Research, Inc.

Most, Kenneth S. (1977) Accounting Theory. Columbus, Ohio: Grid Inc.

Myrdal, Gunnar. (1939) Monetary Equilibrium. London; Edinburgh, Glasgow: William Hodge \& Company, Ltd.

Newlyn, W.T. (1962) Theory of Money. Oxford: Clarendon Press

Niehans, Jurg. (1978) The Theory of Money. Baltimore; London: John Hopkins University Press.

Pareto, Vilfredo. (1927) Manual of Political Economy. Translated by Ann S. Schweir from French edition. Editors A.S. Schweir and A.N. Page, New York: Augustus M. Kelley 1971.

Parker, James E. (1975) "Testing Comparability and Objectivity of Exit Value Accounting." Accounting Review (July).

Paton, William A. and Stevenson, Russell A. (1916) Principles of Accounting. Ann Arbor, Michigan: The Ann Arbor Press. Reprint New York: Arno Press, 1976.

Peasnell, K. V. (1978) "Statement of Accounting Theory and Theory Acceptance: A Review Article." Accounting and Business Research (Summer). 
Powell, Ellis T. (1916) The Evolution of the Money Market 1385-1915: An Historical and Analytical Study of the Rise and Development of Finance as a Centralized Co-ordinated Force. London: The Financial News.

Prest, A.R. (1969) "Replacement Cost Depreciation." Accounting Research, I (1948-1950) cited in Readings in the Concept and Measurement of Income. Edited with an introduction by R.H. Parker and G.C. Harcourt. Cambridge: Cambridge University Press.

Reichenbach, Hans. (1963) The Rise of Scientific Philosophy. Berkeley and Los Angeles: University of California Press.

Roebuck, Carl. (1966) The World of Ancient Times. New York: Charles Scribner's Sons.

Salvary, Stanley C.W. (2006a) “The Behavior Modification Impact of International Accounting Standards on Decision-Making and Risk Management." International Accounting Standards, Regulations, and Financial Reporting. Edited by G. N. Gregoriou and M. Gaber. London: Elsevier Ltd.

(2006b) "Fair Value - The basis of International Financial Reporting Standards: A Conceptual Contradiction of the Relevant Measurement Attribute in Financial Accounting." International Accounting Standards, Regulations, and Financial Reporting. Edited by G. N. Gregoriou and M. Gaber. London: Elsevier Ltd.

. (2004) "Price Level Changes and Financial Accounting Measurement." RePEc:wpa:wuwpot:0410009.

. (2003) "Financial Accounting Information and The Relevance/Irrelevance Issue.” Global Business \& Economics Review V.5 N.2.

(1998a) "Accounting and Financial Reporting in A Changing Environment: Historical and Theoretical Perspectives." Essays in Economic and Business History V.XVI.

(1998b) “The Accounting Variable and Stock Price Determination." Studies in Economics and Finance V.18 N.2.

(1998c) "Financial Accounting Measurement: Instrumentation and Calibnration." Accounting Enquiries V.7 N.2.

. (1997) "On Financial Accounting Measurement: A Reconsideration of SFAC 5 By The FASB Is Needed." The Journal of Applied Business Research (V.13 N.3).

- (1996/1997) "Some Conceptions and Misconceptions on Reality and Assumptions in Financial Accounting." The Journal of Applied Business Research (V13 N.1).

. (1996) "Business Cycles Creation: Some Historical and Theoretical Perspectives." Essays in Economic and Business History (V. XIV: 441-463).

(1993) "On the Historical Validity of Nominal Money as a Measure of Organizational Performance: Some Evidence and Logical Analysis." Essays in Economic and Business History (Vol.XI). 
(1992) "Recoverable Cost: The Basis of a Descriptive Theory of Financial Accounting Measurement," Accounting Enquiries (February).

(1990) "Business Fluctuations and Financial Accounting Measurement: Historical Comments." Essays in Economic and Business History (Volume VIII). . (1989) An Analytical Framework for Accounting Theory. McQueen Accounting Monograph Series, Vol. 5. Fayetteville, Arkansas: University of Arkansas.

(1985) Accounting: A Library of Quantifications. McQueen Accounting Monograph Series, Vol. No.1. Fayetteville, Arkansas: University of Arkansas.

(1981) "An Historical Perspective of The Accounting Environment: A General Outline of A Western European and North American Linkage." Working Paper No. 50. Academy of Accounting Historians Working Paper Series, Vol. 3. Edited by Ashton C. Bishop and Don-Rice Richards. Virginia Commonwealth University, Virginia.

(1979) "Tracing the Development of a Conceptual Framework of Accounting A Western European and North American Linkage: A Partial Examination." Working paper No. 40. Academy of Accounting Historians Working Paper Series, Vol. 2. Ed. by Edward N. Coffman. Virginia Commonwealth University, Virginia.

Samuelson, Paul A. (1961a) "The Evaluation of 'Social Income': Capital Formation and Wealth." The Theory of Capital. Edited by F.A. Lutz and D.C. Hague. London: MacMillan \& Co., Ltd. New York: St. Martin's Press. University Press. (1961b) Foundations of Economic Analysis. Cambridge, Massachusetts: Harvard

Sandilands Committee. (1975) Inflation Accounting. Report of the Inflation Accounting Committee. Chmn. F.E.P. Sandilands. London: Her Majesty's Stationery Office, September.

Schmandt-Besserat, D. (1986) "The Origins of Writing - An Archaeologist's Perspective." Written Communication 3-1, (January).

Shwayder, Keith. (1971) "A Critique of Economic Income as an Accounting Concept," Income Theory and Rate of Return. Edited by J. Leslie Livingstone and Thomas J. Burns. No City: College of Administrative Science, The Ohio State University.

Simmel, Georg. (1978) The Philosophy of Money. Translated byTom Bottomore and David Frisby. London: Henley; Boston: Routledge \&Kegan Paul.

Smirlock, M.; Gilligan, T.; and Marshall, W. (1984) "Tobin's q and the Structure-Performance Relationship." American Economic Review, Vol. 74.

Smith, Bruce D. (1985) "Some Colonial Evidence on Two Theories of Money: Maryland and the Carolinas." Journal of Political Economy. Vol. 93, No.6.

Spindt, Paul A. (1985) "Money is What Money Does: Monetary Aggregation and the Equation of Exchange." Journal of Political Economy. Vol. 93, No.1. 
Sterling, R. R. (1979) Toward a Science of Accounting. Scholars Book Co. Houston, Texas.

Steuart, Sir James. (1767) An Inquiry into the Principles of Political Economy: Being an Essay on the Science of Domestic Policy in Free Nations in Which are Particularly Considered Population, Agriculture, Trade, Industry, Money, Coin, Interest, Circulation, Banks, Exchange, Public Credit, and Taxes. Vol. One. Edited with introduction by A.S. Skinner, Chicago: Reprinted by University of Chicago Press. London: Oliver and Boyd, Ltd., 1966.

Von Mises, Ludwig. (1949) Human Action: A Treatise on Economics. New Haven: Yale University Press.

Walsh, Correa Moylan. (1903) The Fundamental Problem in Monetary Science. New York: The Macmillan Company, London: Macmillan and Co., Ltd.

Weber, Max. (1947) The Theory of Social and Economic Organizations. Translated from the German (part I, Wirtschaft und Gesellschaft) by A.M. Henderson and Talcott Parsons, New York: Oxford University Press, .

Wessel, M. R. (1972) "Computers at Crisis." Computers and Automation (February:10-13).

White, Lawrence H. (1984) "Competitive Payments Systems and the Unit of Account." American Economic Review (September).

Yovits, Marshall C. and Ernst, Ronald L. (1970) "Generalized Information Systems: Consequences for Information Transfer." People and Information. Edited by Harold B. Pepinsky. New York; Oxford; Toronto: Pergamon Press.

Zimmern, Alfred. (1961) The Greek Commonwealth: Politics and Economics in Fifth Century Athens. Fifth edition, revised, New York: Oxford University Press.

\section{Copyright (C) 2007}

